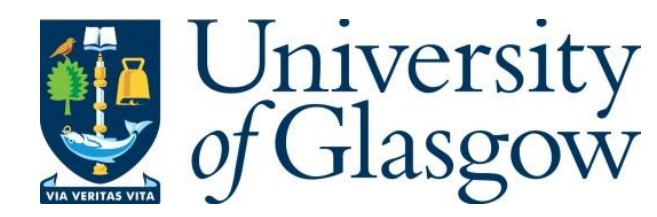

Pickersgill, A. E., Jaret, S. J., Pittarello, L., Fritz, J. and Harris, R. S. (2021) Shock effects in feldspars: an overview. In: Reimold, W. U. and Koeberl, C. (eds.) Large Meteorite Impacts and Planetary Evolution VI. Series: GSA special papers (550). Geological Society of America: Boulder, Colorado, pp. 507-535. ISBN 9780813795508.

There may be differences between this version and the published version. You are advised to consult the publisher's version if you wish to cite from it.

http://eprints.gla.ac.uk/240851/

Deposited on: 6 May 2021

Enlighten - Research publications by members of the University of Glasgow http://eprints.gla.ac.uk 


\section{Shock effects in feldspars: an overview}

2 Annemarie E. Pickersgill ${ }^{1^{*}}$, Steven Jaret ${ }^{2}$, Lidia Pittarello ${ }^{3,4}$, Jörg Fritz ${ }^{5,6}$, and R. Scott

3 Harris $^{7}$

$4{ }^{1}$ School of Geographical \& Earth Sciences, University of Glasgow, Gregory Building, Lilybank

5 Gardens, Glasgow G12 8QQ, U.K.

$6{ }^{2}$ Department of Earth and Planetary Sciences, American Museum of Natural History, New York,

$7 \quad$ NY 10024, U.S.A.

$8 \quad{ }^{3}$ Mineralogisch-Petrographische Abteilung, Naturhistorisches Museum Wien, Burgring 7, A-

$9 \quad 1010$ Vienna, Austria

$10{ }^{4}$ Department of Lithospheric Research, University of Vienna, Althanstrasse 14, A-1090 Vienna,

11 Austria

12 5aalbau Weltraum Projekt, Liebigstraße 6, 64646 Heppenheim, Germany

$13{ }^{6}$ Zentrum für Rieskrater und Impaktforschung Nördlingen (ZERIN), Vordere Gerbergasse 3,

1486720 Nördlingen, Germany

$15{ }^{7}$ Fernbank Science Center, 156 Heaton Park Drive, Atlanta GA 30307, U.S.A.

16 *Corresponding author. E-mail address: annemarie.pickersgill@glasgow.ac.uk(A.E.

17 Pickersgill)

18 ABSTRACT

Feldspars are the dominant mineral in the crust of most terrestrial planetary bodies,

20 including Earth, Earth's moon, and Mars, as well as in asteroids, and thus in meteorites. 
21 These bodies have experienced large numbers of hypervelocity impact events and so it is

22 important to have a robust understanding of the effect that shock waves exert on feldspars.

23 However, due to their optical complexity and susceptibility to weathering, feldspars are

24 under-utilized as shock barometers and indicators of hypervelocity impact. Here, we

25 provide an overview of the work done on shocked feldspars so far, in an effort to better

26 frame the current strengths and weaknesses of different techniques, and to highlight some

27 gaps in the literature.

\section{INTRODUCTION}

Hypervelocity impacts result in distinctive microstructural deformation in rocks and

30 minerals during passage of a shock wave (e.g., French and Short, 1968; Roddy et al., 1978;

31 Stöffler and Grieve, 2007; French and Koeberl, 2010). This shock metamorphism records the

32 pressure, temperature, and strain rate conditions experienced by geo-materials during crater

33 formation. Understanding the shock metamorphic overprint of planetary materials is crucial to

34 the study of meteorites, terrestrial impact structures, and samples returned to Earth by space

35 missions. Clear criteria for characterizing and quantifying the degree of shock metamorphism are

36 required together with an understanding of how shock metamorphism affects different

37 lithologies.

Shock metamorphic effects vary between rock types due differences in the mineralogy

39 and microstructural characteristics of the target (e.g., French and Koeberl, 2010; Ferrière and

40 Osinski, 2013 and references therein). This observation has been used to propose multiple shock

41 classification schemes for different rock types including meteorites (e.g., Fritz et al., 2017),

42 quartzofeldspathic rocks, sandstones, basaltic-gabbroic rocks, particulate rock material,

43 chondritic and dunitic rocks (Stöffler et al., 2018). Shock effects are mineralogically selective, 
44 and heterogeneous in spatial distribution, such that neighbouring minerals, even if the same

45 composition, may record different effects. This is due to differences in the shock impedance, a

46 physical property of matter that describes how efficiently a shock wave propagates through a

47 material. The mineral grains and pore spaces composing a polymineralic rock have different

48 shock impedances, hence the shock wave propagates with variable efficiency, and this leads to a

49 heterogeneous distribution of the maximum shock pressure and resultant shock metamorphic

50 effects within a sample (e.g., Ogilvie et al., 2011). In addition, the degree and type of

51 deformation is affected by the mineral's crystal structure and composition (Stöffler, 1972), pre-

52 impact temperature (e.g., Langenhorst et al., 1992; Huffman et al., 1993; Langenhorst and

53 Deutsch, 1994; Fritz et al., 2011) and pre-impact stress conditions (Daniel et al., 1997; Sims et

54 al., 2019). Shock deformation of most minerals is evidenced by a progressive degradation of the 55 crystal structure until melting occurs.

Feldspar group minerals (alkali feldspar and plagioclase) are both chemically and

57 optically complex. Various publications address shock metamorphism for plagioclase, a major

58 component in planetary materials, including asteroids, Mars, Earth, and Earth's moon. However,

59 the K-rich alkali feldspars that are rare in meteorites but abundant in terrestrial rocks, have not

60 been studied in as much detail. Feldspar group minerals suffer from alteration in a hydrous

61 environment rendering them challenging to study using solely optical microscopy. Additionally,

62 pre-existing microstructures, such as twin planes, cleavage planes, and exsolution lamellae,

63 might be masking or possibly even precluding the formation of shock-generated planar features.

64 The aforementioned challenges to studying feldspar microstructures coupled with inconsistencies

65 in the features associated with different shock levels in different rock types (e.g., Stöffler et al.,

66 2018; Fritz et al., 2017) make the utility of feldspars as a shock thermo-barometer variable. 
Despite their abundance in rocky planetary materials, feldspars have been under-utilized

68 for shock barometry compared to quartz and olivine. However, feldspar is becoming increasingly

69 popular for shock barometry (e.g., Jaret et al., 2014; Kayama et al., 2018; Fritz et al., 2019a). In

70 this paper, we discuss all impact cratering related effects on the feldspar group, but the reader

71 should note that only definitive planar deformation features (PDFs), and diaplectic glass are

72 considered diagnostic shock effects on their own (French and Koeberl, 2010). Certain high-

73 pressure polymorphs can also be diagnostic, but only given a proper geologic context. Diagnostic

74 shock effects are those that only form via passage of a shock wave with a strain rate and a

75 pressure-temperature-time (P-T-t) path that cannot be produced by endogenic processes.

76 Additional microstructures can form during impact cratering events but can also form by other

77 geological processes. For example, fractures, kink bands, mosaicism, and darkening can inform

78 the degree to which feldspars have been shocked, but these features can also be produced

79 endogenically. Even tectonically-induced amorphization is possible, although only under

80 extreme and rare conditions such as those reported for silica by Janssen et al. (2010).

\section{2. Feldspar Group Minerals}

Feldspars are the most abundant mineral group in crustal rocks on Earth (Deer et al.,

83 2001), as well as in the crustal rocks of terrestrial planetary bodies (Papike et al., 1991). The

84 feldspar group is composed of two solid solutions: alkali feldspar $\left(\mathrm{NaAlSi}_{3} \mathrm{O}_{8}-\mathrm{KAlSi}_{3} \mathrm{O}_{8}\right)$ with a

85 density of $2.62-2.55 \mathrm{~g} / \mathrm{cm}^{3}$ and plagioclase feldspar $\left(\mathrm{NaAlSi}_{3} \mathrm{O}_{8}-\mathrm{CaAl}_{2} \mathrm{Si}_{2} \mathrm{O}_{8}\right)$ with a density of

$862.62-2.76 \mathrm{~g} / \mathrm{cm}^{3}$. Intergrowths of alkali and plagioclase feldspars are common, such as perthite

87 (albite lamellae in K-feldspar host) and antiperthite (K-feldspar lamellae in albite). The crystal

88 system is triclinic or monoclinic, depending on composition, thermal history, and crystallization

89 temperature. Planar microstructures that are common in feldspar are good cleavage $(\{001\}$ and 
$90\{010\}$ ) and the formation of twins (Seifert, 1964; Zoltai and Stout, 1984; Xu et al., 2016 and

91 references therein). Common twins in alkali-feldspar are Carlsbad, with the z-axis as twin axis,

92 and Baveno, with (021) as twin axis, and a combination of albite and pericline twinning,

93 resembling a "tartan" pattern (Deer et al., 2001).

94 On planetary bodies with active hydrospheres, plagioclase routinely alters to sericite,

95 zeolites, or clay group minerals. These products can locally be replaced by secondary calcite, due

96 to hydrothermal alteration (e.g. Leichmann et al., 2003; Pittarello et al., 2013). A typical product

97 of hydrothermal alteration of plagioclase is "saussurite", an old term used to indicate a mixture

98 of zoisite, epidote, sericite, and other components.

\section{3. Shock effects in Feldspars}

Shocked feldspar from impact structures on Earth, meteorites, and shock recovery experiments displays a range of shock-induced microstructures including undulatory extinction,

102 mosaicism, planar microstructures, diaplectic glass, and melted (i.e., flow-textured and/or

103 vesiculated) feldspar glass (Table 1, e.g., Stöffler, 1967; Stöffler et al., 2018). These effects

104 result from progressive breakdown of the crystal lattice, and are linked with a specific range of

105 shock pressures, temperatures, and anorthite content, as determined by high-pressure 106 experiments (Fig. 1).

107 The state of matter under shock compression can be described with Hugoniot curves

108 (e.g., Melosh, 1989; Langenhorst, 2002; Langenhorst and Deutsch, 2012; Fritz et al., 2017),

109 which are depicted, for a specific mineral, in a density (or specific volume) vs. pressure plot.

110 Figure 2 shows experimental data on anorthosite (rock composed mainly of Ca-rich plagioclase)

111 derived from particle and shock wave velocity measurements at given shock pressures, with the 
112 specific volume calculated via the Rankine-Hugoniot relations. The Hugoniot is not a

113 representation of a gradual increase in pressure and density, but describes the possible states

114 achieved by a material that discontinuously jumps across the shock front from the uncompressed

115 to the compressed state. The Hugoniot Elastic Limit (HEL) of a material indicates the transition

116 from a purely elastic state to an elastic-plastic state. For feldspars, the HEL has been measured at

117 3.5-4.5 GPa. Pressures in excess of this range cause permanent changes in feldspar crystal

118 structures (Ahrens et al., 1973; Grady and Murri, 1976; Huffman and Reimold, 1996). In

119 addition, the Hugoniot of feldspar is subdivided into Regions I to III, which mark pressures

120 above which the compressibility of the material during shock changes substantially. These

121 regions correspond to specific shock metamorphic effects - the physical manifestation of the

122 pressure-volume work during shock. Hence, shock effects from fracturing, kinking, and

123 mosaicism, to formation of planar microstructures, diaplectic glass, and melting can be linked to

124 a range of shock pressures. In order to appropriately extrapolate a shock pressure estimate to the

125 whole rock, one must consider numerous grains throughout the sample, ideally in a variety of

126 minerals. In the following sections, we provide an overview of the effects produced in feldspars

127 during hypervelocity impact, both diagnostic (unique to impact) and non-diagnostic (formed both 128 during impact and endogenically).

\section{3.1. Fracturing}

$130 \quad$ Fracturing is pervasive in rocks affected by impact (Fig. 3). The density of impact-

131 induced fractures in quartz and feldspars has been found to increase with increasing pressure up

132 to $\sim 20 \mathrm{GPa}$ (Lambert 1979). However fracture density decreases as pressure increases above

$133 \sim 20 \mathrm{GPa}$. Lambert (1979) concluded that the correlation between fracture density and pressure 
134 was too weak to be used for quantitative pressure calibration. Fractures are rare or absent in

135 partly or fully isotropic feldspars (see Section 3.7).

\section{3.2. Undulatory extinction}

Undulatory (or undulose) extinction is the optical effect of a wave of extinction sweeping

138 through a single crystal as the microscope stage is rotated with the sample between crossed

139 polarizers; i.e., the entire crystal does not go in and out of extinction simultaneously (Fig. 4).

140 This optical effect is the result of bending of the crystal structure without fracturing. Undulatory

141 extinction is a common effect in minerals that have experienced non-uniform strain, and is not

142 diagnostic of shock metamorphism, however it can be informative. For example, the amount of

143 stress that a crystal has experienced can be qualitatively estimated based on how undulatory the

144 extinction is; i.e., approximately how much variation in extinction angle is displayed within a

145 single crystal? A higher amount of variation records higher strain. There is potential to quantify

146 this effect using a Universal stage (U-stage) or electron backscatter diffraction (EBSD)

147 measurements of the misorientation of the optic axes, however, we are not aware of any

148 systematic studies attempting to quantify undulatory extinction in feldspars. Such efforts would

149 be unlikely to develop a robust correlation given the ubiquitous nature of undulatory extinction

150 as a result of tectonic deformation $(\mathrm{P}<<1 \mathrm{GPa})$.

\section{$151 \quad 3.3 . \quad$ Optical Mosaicism}

Optical mosaicism is an extinction pattern observed in crystals composed of numerous

153 subdomains, with differently oriented optic axes (e.g., Dachille et al., 1968; Stöffler, 1972;

154 Stöffler and Langenhorst, 1994; French and Koeberl, 2010). This extinction pattern is different

155 from undulatory extinction in which extinction passes smoothly through the crystal during 
156 rotation of the microscope stage. In mosaicism, subdomains are only a few micrometers in size,

157 hence several rotated subdomains overlap in a typical $\sim 30 \mu \mathrm{m}$ thick thin section. Mosaicism is

158 best observed in transmitted light between crossed polarizers, where it appears as a patchwork of

159 extinction domains; with EBSD, as a patchwork of crystallographic orientations; or with single-

160 crystal or in situ X-ray diffraction (XRD), producing arcs of diffraction spots instead of single

161 spots. A similar pattern of extinction is also caused by endogenic processes (e.g., Spry, 1969;

162 Vernon, 1975), so optical mosaicism cannot be used as a unique diagnostic indicator of shock

163 metamorphism.

\section{3.4. Planar microstructures}

165 Shock related planar microstructures in feldspars include planar fractures (PFs), planar

166 deformation features (PDFs), deformation bands, and kink bands (e.g., Stöffler, 1967, 1972;

167 French and Short, 1968; French, 1998). PFs and PDFs in feldspar are not as well characterized as

168 those in quartz, so we start with a brief discussion of these features in quartz to frame the

169 discussion. In quartz, PFs are open cracks, typically $>3 \mu \mathrm{m}$ wide, and spaced $\sim 15-20 \mu \mathrm{m}$ apart;

170 PDFs are lamellae composed of amorphous (or recrystallized) $\mathrm{SiO}_{2},<2 \mu \mathrm{m}$ wide, and spaced

171 2-10 $\mu$ m apart (e.g., Engelhardt and Bertsch, 1969; Stöffler and Langenhorst, 1994;

172 Langenhorst, 2002). Both PFs and PDFs are planar and form parallel to rational crystallographic

173 orientations (French and Short, 1968; French et al., 2004).

174 Early reports of what are now referred to as PDFs in feldspar were described as various

175 types of lamellae in plagioclase by both Stöffler (1967) and Dworak (1969). Stöffler (1967)

176 described 1-8 $\mu \mathrm{m}$ thick isotropic (or low birefringence) lamellae spaced a few micrometers apart,

177 similar to planar features described in quartz. Dworak (1969) described several types of lamellae,

178 equivalent to deformation bands, PDFs, and PFs. The lamellae described as being most similar to 
179 quartz PDFs are 2-5 $\mu \mathrm{m}$ thick isotropic (or low birefringence) lamellae spaced about $10 \mu \mathrm{m}$

180 apart, sometimes decorated with small inclusions. Dworak (1969) described feldspar PFs as up to

$18110 \mu \mathrm{m}$ wide open fractures spaced a few micrometers apart and forming preferentially at grain

182 margins.

183 In feldspar, PDFs occurring along with more widely spaced features (i.e., deformation

184 bands or twins) form a ladder texture (Fig. 5) (e.g., Stöffler, 1967, 1972; Engelhardt and Stöffler,

185 1968; French and Short, 1968). Pittarello et al. (2013) reported microstructures in plagioclase

186 that resemble feather features (FFs) previously described for quartz (Poelchau and Kenkmann,

187 2001), however no systematic study has yet been conducted on apparent FFs in feldspars. Sets of

188 thin alternating isotropic lamellae $(<10 \mu \mathrm{m}$ wide) oriented parallel to the most common

189 plagioclase twins have been reported as shock-induced microtwins (e.g., Stöffler, 1966; Dworak,

190 1969; Stöffler, 1972), though it has yet to be confirmed whether the formation of the microtwins

191 is due to shock metamorphism, nor whether the currently isotropic lamellae originated as twin

192 lamellae.

A great many planar microstructures exist in feldspars to begin with, so using an optical

194 microscope alone to fully characterize putative PDFs is challenging, and it is better combined

195 with high-resolution techniques such as electron microscopy. Pickersgill et al. (2017)

196 investigated planar microstructures in Or-rich alkali feldspar from granitoid rocks from the

197 Chicxulub impact structure using EBSD combined with transmission electron microscopy

198 (TEM). EBSD highlighted semi-planar microstructures visible in transmitted light parallel to the

199 trace of $\{001\},\{010\}$, and $\{100\}$. Follow up TEM work revealed that the "planes" are in fact

200 semi-coherent subgrain boundaries that are neither straight nor parallel (spacing varies from 0.2-

$2010.6 \mu \mathrm{m}$ between adjacent boundaries), and have no indication of amorphous material, making 
202 these subplanar microstructures distinct from the strict definition of PDFs as defined in quartz.

203 The microstructures parallel to $\{110\}$ form lamellar subgrains that, despite resembling strain-

204 induced twins, are too closely spaced and narrow to be twins. Likewise, they are not exsolution

205 lamellae as they show no chemical variation. Pittarello et al. (2020a) conducted EBSD on

206 shocked plagioclase grains in a meta-granite from the Manicouagan impact structure, Canada.

207 Results suggest that amorphization in plagioclase begins either within pre-shock twins or along

208 shock-induced lamellae that are similar to both PDFs and micro-twins, likely representing

209 structural failure of specific crystallographic planes during shock. Attempted indexing of these

210 features using EBSD and U-stage resulted in orientations of $\{001\},\{010\}$, and $\{1 \overline{2} 0\}$ or $\{1 \overline{3} 0\}$

211 (ambiguous).

212 PDFs in feldspars and quartz are reported to start to form at about the same pressure ( $>8$

213 GPa, Stöffler, 1971; Ostertag, 1983), and are no longer present in samples subjected to pressures

214 high enough to cause amorphization of the mineral (24-35 GPa). PDFs in feldspars have been

215 reported for various impact structures including Ries (Stöffler, 1966; Engelhardt and Stöffler,

216 1968); Sudbury (French, 1968); Manicouagan (Dworak, 1969; Dressler, 1990; White, 1993);

217 Gardnos (French et al., 1997); Tenoumer (French et al., 1970; Jaret et al., 2014); Dhala (Pati et

218 al., 2010); and El'gygytgyn (Pittarello et al., 2013). Overwhelmingly, these are noted in passing

219 as an accessory to PDFs in quartz, with rare attention or detail given to the PDFs in feldspar. As

220 a result, the compositional range of feldspars bearing PDFs are rarely noted, but from the limited

221 examples, PDFs appear to be confined to alkali feldspar or low-Ca $\left(<A n_{\sim 50}\right)$ plagioclase

222 (Langenhorst et al., 1995; Trepmann et al., 2003; Gibson and Reimold, 2005; Nagy et al., 2008;

223 Pittarello et al., 2013; Jaret et al., 2018), and are generally absent in higher Ca-plagioclase even

224 for samples in shock ranges expected to form PDFs. For example, at the Mistastin Lake impact 
225 structure, PDFs are abundant in quartz, and completely absent in plagioclase $\left(\mathrm{An}_{31-55}\right)$

226 (Pickersgill et al., 2015b). Similarly, at the Lonar Crater, India, which is a basaltic target with

227 highly calcic plagioclase, no PDFs have been identified despite abundant examples of diaplectic 228 glass (Kieffer et al., 1976; Jaret et al., 2015). However, we are aware of two exceptions to the

229 high-Ca plagioclase resistance to PDFs, both in lunar anorthite, from the meteorite Oued Awlitis

230001 (Wittmann et al., 2019), and Apollo sample 10046 (Dence et al., 1970). This indicates a

231 strong compositional (and therefore crystallographic) effect on whether or not PDFs form in

232 feldspars. The lack of observed planar features in experimentally shocked plagioclase $\left(\mathrm{An}_{63}\right)$ led

233 Gibbons and Ahrens (1977) to suggest that the presence of PDFs in plagioclase is not as

234 diagnostic of shock as maskelynite, and that PDFs would represent a purely local effect.

\section{3.5. Shock darkening}

Shock darkening is a reduction in the transparency of a mineral in transmitted light (e.g.,

237 Reimold and Miller, 1989; French et al., 1997; Jaret et al., 2018). This optical phenomenon is a

238 common shock feature in mafic silicates, but has also been observed in feldspars (Fig. 6). Shock

239 darkening of silicates is attributed to submicroscopic Fe-bearing droplets, that are mobilized and

240 concentrated at shock conditions prior to melting (e.g., Rubin, 1992; Moreau et al., 2017). Shock

241 darkening has been described in terrestrial shocked feldspars at the Gardnos (French et al.,

242 1997), Manson (Koeberl et al., 1996), Roter Kamm (Reimold and Miller, 1989), and Sudbury

243 (French, 1968) impact structures. Shock darkening has also been observed in experimentally

244 shocked andesine, albite, and bytownite (Jaret et al., 2018). In plane-polarized light samples

245 shocked between 17 and $50 \mathrm{GPa}$ all show a pronounced darkening that is inherent to the samples

246 and not a surface coating, nor does it correspond to elemental composition at the spatial

247 resolution of the electron microprobe, which supports the attribution of darkening to sub- 
248 micrometer Fe-droplets. To our knowledge no atomic level study of shock darkened feldspars

249 has been conducted. This effect is superficially similar to clouded feldspar, but can be

250 differentiated in that in clouded feldspar the features are usually resolvable with an optical

251 microscope (e.g., Poldervaart and Gilkey, 1954; Whitney, 1972; Smith and Brown, 1988; Putnis

252 et al., 2007).

\section{3.6. Alternate twin deformation}

An effect observed in some feldspars is the deformation of only alternate twins in, for 255 example, a polysynthetically twinned plagioclase. This alternate twin deformation includes the

256 formation of possible PDFs in every other twin (forming a ladder texture or alternate twin

257 lamellae, Fig. 5a,b), and the formation of diaplectic glass (alternate twin isotropisation).

258 Alternate twin effects are interpreted to occur in response to "favorable" crystallographic

259 orientation of one twin set with respect to the local shock wave (Stöffler, 1966, 1967; Taylor and

260 Dence, 1969; Robertson, 1973; Dressler, 1990; Jaret et al., 2014; Pickersgill et al., 2015b;

261 Pittarello et al., 2020a). Jaret et al. (2014) interpreted alternate twin deformation to indicate

262 relatively low pressure conditions where subtle orientation differences are enough to impede

263 shock deformation, whereas at higher shock conditions there is so much energy that slight

264 misorientations do not affect the deformation process. Likewise, Pickersgill et al., (2015a) used

265 in situ micro X-ray diffraction ( $\mu \mathrm{XRD}$ ) to find that adjacent twin sets generally deform to the

266 same degree, which they interpreted to mean that the difference in lattice orientation between

267 twins relative to the shock wave that causes alternate twin deformation occurs over a very

268 narrow range of orientations.

\section{3.7. Diaplectic glass}


271 phases which are optically isotropic (i.e., extinct on rotation of the stage between crossed

272 polarisers); amorphous to Raman, X-ray diffraction, or other techniques that measure

273 crystallinity; but still retain the exact chemical composition, and morphology of the precursor

274 mineral thereby preserving the original rock fabric (Fig. 7) (e.g., Engelhardt et al., 1967; Binns,

275 1967; Engelhardt and Stöffler, 1968; Hörz and Quaide, 1973). Diaplectic glasses do not exhibit

276 flow textures or vesiculation, even when observed using high resolution imaging techniques such

277 as scanning electron microscopy (SEM). Preservation of the internal fabric is indicated by

278 preservation of, for example, magmatic pyroxene lamellae in maskelynite from the Martian

279 meteorite Shergotty (Fig. 7) and Fe-oxide "clouding" in diaplectic plagioclase glass from the

280 Mistastin Lake impact structure (Pickersgill et al., 2015b). Even chemical zonation is preserved

281 in diaplectic plagioclase glass from both terrestrial impact structures (Jaret et al., 2015) and

282 meteorites (Treiman and Treado, 1998). The transition from crystalline (i.e., birefringent)

283 feldspar to diaplectic feldspar glass is documented by grains in which some areas are amorphous,

284 and some areas remain birefringent. This transition can manifest as alternate twin isotropisation

285 (Stöffler, 1966, 1971; French, 1998), but is equally found unrelated to twins or other planar

286 features (Fig. 7C,D, e.g., Pickersgill et al., 2015b; Pittarello et al., 2020a, 2020b). Both partially

287 and fully isotropic diaplectic glasses are characterized by a lack of fracturing, even when 288 surrounded by highly fractured minerals (Fig. 7 a,b).

289 3.7.1. Identification

In transmitted light, initial suspicion of diaplectic glass comes from noting a grain that is

291 constantly extinct between crossed polarizers. In reflected light or during SEM of a polished

292 surface (thin or thick section), initial inference of diaplectic glass comes from observing a 
293 notable pattern of fractures: fractures are rare or absent in partly and fully isotropic feldspar and

294 fractures in adjacent minerals such as olivine and pyroxene terminate at the interface with the 295 diaplectic glass (see Fig. 7 a,b).

In order to definitively identify diaplectic glasses, it is crucial to ensure that the phase

297 being examined is 1) amorphous, and 2) the same composition as feldspar. Permanent extinction

298 under an optical microscope can indicate a) an amorphous phase; b) orientation of an optic axis

299 of a crystal parallel to the line of sight of the microscope (perpendicular to the thin section

300 surface); and c) naturally isotropic minerals (e.g., garnet). It is therefore necessary to confirm an

301 amorphous state using additional techniques such as obtaining an interference figure using the

302 Bertrand lens of the microscope (no interference figure should be present with an amorphous

303 phase), or using a U-stage to rotate the sample out of extinction. If the phase is indeed

304 amorphous, in situ $\mu$ XRD will reveal a diffuse band across the detector rather than distinct

305 diffraction spots. Likewise, Raman spectra of amorphous feldspar have two broad peaks of

306 relatively low intensities at $\sim 400-600 \Delta \mathrm{cm}^{-1}$ and $\sim 1000-1100 \Delta \mathrm{cm}^{-1}$ (Fig 14). Composition

307 should be confirmed using an analytical SEM or electron probe microanalysis (EPMA).

\subsubsection{Structure}

The amorphous nature of diaplectic glasses suggests that they have lost the ordered

310 internal atomic arrangement of the precursor crystal. However, diaplectic feldspar glasses

311 display several properties that indicate a transitional state between a crystal and a glass produced

312 by quenching of a molten mineral (i.e., a monomineralic melt glass):

313 1) Diaplectic plagioclase glass has a density and refractive index (RI) intermediate between

314 a plagioclase crystal and a melt glass of identical chemical composition (Engelhardt et al. 
1967;Ostertag 1983; Fritz et al. 2019a). Both density and RI decrease with increasing

316 shock level (Arndt et al., 1982, see Fig. 8);

2) Diaplectic glasses maintain substantial intermediate-range structural order, unlike melt glasses (e.g., Milton and de Carli, 1963; Bunch et al., 1967; Arndt et al., 1982; Ostertag, 1983; Jaret et al. 2015).

3) Diaplectic plagioclase glass retains a structural memory of its former crystalline state (Milton and de Carli, 1963; Bunch et al., 1967; Hörz and Quaide, 1973; Arndt et al., 1982; Diemann and Arndt, 1984; Jaret et al., 2015).

When heated at ambient pressure, diaplectic glasses can recrystallize back into a single crystal, which is distinctly different from melt glass, which always reverts to a polycrystalline aggregate (Bunch et al., 1967; Arndt et al., 1982). Sometimes these recrystallized feldspars even regain undulatory extinction. Further investigations into the memory effects of diaplectic glass have been investigated using high-pressure experiments and are discussed in Section 4.

Structural differences between melt glass and diaplectic glass have been investigated by a number of techniques. Synchrotron X-ray total scattering experiments of crystalline plagioclase, natural diaplectic plagioclase glass, and fused plagioclase glass (all of labradorite composition) show that both glasses are characterized by lack of periodicity beyond distances of $10 \AA$, unlike crystalline plagioclase (Jaret et al., 2015). However, in the intermediate range (4-10 $\AA$ ) the diaplectic glasses show a higher degree of atomic order than melt glasses (Jaret et al., 2015). Orientation sensitive measurements on diaplectic glass have suggested retention of orientation and position of some atoms despite loss of long-range order. Micro-FTIR spectroscopy of individual naturally and experimentally shocked plagioclase grains is also sensitive to 
337 orientation, where peak positions and intensities of vibrational modes in plagioclase can shift by

$338 \sim 40$ wavenumbers, making it difficult to correlate changes in peak intensities or positions with

339 shock level (Fig. 9). However, the degree to which orientation affects the spectra decreases with

340 increasing shock level (Jaret et al., 2015). Orientation effects have been found to be a useful tool

341 for distinguishing between diaplectic and melt-produced glasses. For example, in infrared

342 spectroscopy diaplectic labradorite glass exhibits one Si-O stretching band, but this peak position

343 changes by 40 wavenumbers upon rotation of the grain (Fig. 9). Melt glass on the other hand

344 does not show effects of orientation on spectral position (Jaret et al., 2015). Nuclear magnetic

345 resonance (NMR) spectroscopy shows the overall spectral shape and pattern of diaplectic

346 labradorite glass is similar to that of crystalline plagioclase, suggesting a lack of large-scale

347 differences in structure or silica polymerization. Fused labradorite glass on the other hand has a

348 larger difference in chemical shift in NMR spectra compared to crystalline labradorite, further

349 supporting that diaplectic plagioclase glass and fused plagioclase glass are structurally different

350 (Jaret et al., 2015).

\section{3.7.3. Alteration}

In a hydrous environment, feldspars and diaplectic glass are susceptible to alteration. As

353 a result, recrystallized feldspars are typical in terrestrial impactites. The resultant textures are

354 described as spherulitic or plumose microcrystals, interpreted as evidence of altered diaplectic

355 glasses during post-shock heating (French, 1998). This effect occurs in the Manson impact

356 structure, where shocked plagioclase appears to have highly altered alternating twins (Short and

357 Gold, 1996). Likewise, at the Mistastin Lake impact structure, alternating twins in some samples

358 have altered to zeolites (Pickersgill et al., 2015b). In both cases, these textures are interpreted as

359 preferential alteration of diaplectic glass in grains that underwent alternate twin isotropization. 
Fully isotropic diaplectic feldspar glass forms by the passage of a shock wave with

362 pressures of more than 24-30 GPa and less than $\sim 47 \mathrm{GPa}$ (Table 1, Ostertag, 1983; Jaret et al.,

363 2018; Fritz et al., 2019a). Both meteorites and terrestrial impactites have documented a

364 relationship between the formation of diaplectic plagioclase glass from plagioclase in contact

365 with shock melt veins (Walton et al., 2016; Sharp et al., 2019). In these cases, plagioclase further

366 from melt veins, or in contact with thin $(1-4 \mu \mathrm{m})$ veins remains crystalline, but plagioclase in

367 contact with melt veins has become isotropic. The formation of diaplectic glass is therefore

368 attributed to the elevated temperature gradient caused by contact with shock melt, combined with

369 the large deviatoric stresses experienced by minerals along vein margins. These natural

370 observations agree with experimental results that demonstrate that both elevated temperature and

371 shear stress reduce the pressure at which plagioclase transforms to diaplectic glass (e.g., Kubo et

372 al., 2010; Daniel et al., 1997). There is a strong compositional effect on the pressures associated

373 with amorphization, where more calcic plagioclase becomes amorphous at lower pressure

374 conditions (Ostertag, 1983; Angel, 1994; Fritz et al., 2019a; Jaret et al., 2018). Most likely this

375 trend reflects the Si-Al polymerization rather than Ca content directly (Angel, 1994; Jaret et al.,

376 2018). There has been significantly less work on quantifying the differences in shock response

377 between the alkali-series feldspars. Ostertag (1983) reported amorphization of experimentally

378 shocked sanidine and orthoclase at pressures of $\sim 30$ and $\sim 32 \mathrm{GPa}$, whereas microcline retained

379 some birefringence up to pressures of $45 \mathrm{GPa}$.

The transitional regime between diaplectic and melt glasses results in shock-temperatures

381 in plagioclase that are not high enough to cause melting of the whole grain, but are just high 
382 enough to cause eutectic melting along plagioclase/pyroxene interfaces (Fig. 7) and assimilation

383 of minerals with a lower melting point.

\section{3.8. Melting}

At higher shock pressure monomineralic melt glass forms with the same composition as

386 the original feldspar (e.g., Stöffler, 1972, 1967). An example of fully melted plagioclase glass is

387 shown in Fig. 10, in the strongly shocked Martian meteorite ALH 77005. Petrographically

388 melted feldspar glass is significantly different from diaplectic feldspar glass in that melt glass

389 displays flow textures and/or vesicles.

Upon cooling, if the pressure pulse is longer than the undercooling, high pressure phases

391 can crystallize from the melt (e.g., Sharp and DeCarli, 2006; Walton et al., 2014). Small

392 occurrences of plagioclase-composition melt glass can be identified by careful high-resolution

393 backscatter electron imaging (El Goresy et al., 2013). Care must be taken to ensure that apparent

394 feldspar-composition glasses are not whole-rock melts using EPMA or analytical SEM. Feldspar

395 melting is associated with local peak shock pressure of $\sim 45-50 \mathrm{GPa}$, however melting can occur

396 in porous targets shocked to lower pressures, where the shock kinetic energy is mostly converted

397 into heat (e.g., Kieffer, 1971; Davison et al., 2010).

\section{3.9. High pressure polymorphs}

The temperatures during shock are such that weakly to strongly shocked rocks can serve

400 as a heat sink allowing localized zones of shock melt to quickly cool by assimilation and thermal

401 conduction during elevated shock pressure conditions. Therefore, localized zones of shock melt

402 (10s to 100s of micrometers in size) provide the pressure-temperature-time path (P-T-t) allowing

403 for the formation and preservation of a variety of high-pressure phases (Tomioka and Miyahara, 
404 2017; Fritz et al., 2017). These local zones of shock melt serve as natural crucibles mimicking

405 the conditions in the Earth's lower crust or mantle. High-pressure minerals are not common in

406 Earth's upper crust, but they are produced endogenically and therefore can only be related to

407 shock when observations are combined with relevant geologic context (French and Koeberl,

408 2010). A list of high-pressure minerals related to shocked feldspar is given in Table 2, together

409 with their chemical formulae, experimentally derived pressure and temperature (P-T) stability

410 fields and references. High-pressure phases have been identified in most types of meteorites, in

411 various rocks from terrestrial impact structures, and synthesized in high-pressure laboratory

412 experiments. This indicates that formation and preservation of high-pressure phases is a typical

413 result of impact cratering events.

\section{3.10. Sieve-texture and checkerboard feldspar}

415 "Checkerboard" feldspar is a checkered-looking pattern of subgrain domains found

416 within feldspar clasts in impact melt rocks (Fig. 11). Checkerboard texture has the appearance of

417 crystallographically controlled individual rectangular domains separated by melt products (e.g.,

418 Grieve, 1975). Internal features such as twinning and extinction angle are preserved across the

419 grains demonstrating that they were once a single crystal (Fig. 11). This texture was originally

420 termed "checkerboard" by Grieve (1975), who described unshocked partly digested plagioclase

421 inclusions in a melt rock with a sieved, "checker-board" appearance due to thermal effects of the

422 surrounding melt. Bischoff and Stöffler (1984) first proposed a detailed scenario for

423 development of sieve texture in clasts in impact melt rock from the Lappajärvi impact structure

424 (Finland). Their scenario essentially regarded checkerboard texture as the result of rapid,

425 crystallographically-controlled recrystallization from diaplectic feldspar glass, comparable to the 
426 suggested formation of ballen quartz (e.g., Ferrière et al., 2010). As such, the texture would

427 represent positive evidence of transient shock pressures exceeding 25-35 GPa.

428 Whitehead et al., (2002) revised the formation of checkerboard texture based on feldspar

429 clasts in melt rocks from the Popigai impact structure. Their scenario more closely resembles the

430 disequilibrium melting of plagioclase observed during the rapid decompression of intermediate

431 composition magmatic systems, resulting in typical (i.e., igneous) "sieve-textured" feldspar

432 (Nelson and Montana, 1992). Whitehead et al. (2002) noted similar textures in clinopyroxenes in

433 the Popigai impact melt rocks, which are also commonly associated with so-called "sieve-

434 textured" feldspars in volcanic rocks.

435 A texture similar to checkerboard feldspar occurs in volcanic rocks, and is also referred

436 to as "sieve texture". The images that accompany the igneous definition of "sieve texture" (Klein

437 and Philpotts, 2016) imply crystallographic control of the melt channels. This can lead to

438 confusion when the terms "sieve-texture" and "checkerboard texture" are used interchangeably,

439 because there are two genetic interpretations for a similar appearance: i) volcanic chemically

440 driven disequilibrium melting (Nelson and Montana, 1992) and ii) impact-induced

441 crystallographically controlled disequilibrium melting (Whitehead et al., 2002).

442 Whitehead et al., (2002) attempted to distinguish impact melting from igneous melting

443 based on the optical crystallography and X-ray element mapping of subgrains within the feldspar

444 clasts. However, it is not clear from their observations that distinguishing these two processes is

445 possible (Harris et al., 2019). Therefore, it has not been convincingly shown that the sieve

446 texture of igneous petrologists and the sieve or checkerboard texture of impact petrologists are

447 the result of different processes. Consequently checkerboard or sieve-texture feldspar, while

448 common in both volcanic and impact melt rocks, should not be used as a unique diagnostic 
449 criterion of either process unless significant progress is made in differentiating igneous sieve

450 texture from impact-induced sieve or checkerboard texture.

\section{4. Experimental Shock Calibrations}

High-pressure experiments enable formation conditions (i.e., pressure, temperature,

453 timing) to be assigned to rock and mineral samples based on the microscopic textures produced.

454 Such experiments are conducted using four main techniques: 1) shock experiments; 2) shock

455 recovery experiments; 3) rapid compression experiments; 4) static compression experiments.

456 These different techniques (1-4 in previous sentence, summarized in Table 3) create different

457 physical conditions. As a result, the same high-pressure effects (e.g., amorphization) may

458 develop at different pressure and temperature conditions depending on the experimental process

459 and the characteristics of the test material (i.e., initial grain size, composition, porosity, presence

460 of structural defects, etc.). Therefore, the reported experimental data need careful evaluation

461 before comparing results between different experiments and their application to natural shock

462 metamorphism. The experimental setups mentioned previously could influence the pressures at

463 which specific microstructural deformation is observed in several ways:

464 1) By studying the samples in a compressed or decompressed state, i.e., in situ during static 465 pressure experiments or after decompression to ambient pressure from static pressure 466 experiments (Daniel et al., 1997; Johnson et al., 2002a, 2003; Kubo et al., 2010; Jaret et 467 al., 2018).

468 2) By applying hydrostatic or non-hydrostatic conditions to the sample (Daniel et al., 1997)

469 3) By changing the rate at which the sample is compressed (e.g., Sims et al., 2020) 
4) By changing the duration of the high-pressure conditions (Huffman et al., 1993; Kubo et al., 2010; Ogilvie et al., 2011; Fritz et al., 2019a); and,

In addition, experimental measurements of the shock wave and particle velocity

parameters allow for calculation of the pressure, density, and energy of the compressed material using the Rankine-Hugoniot relations (Fig. 2). These different experimental approaches have provided a variety of complementary information on material properties during shock compression and after decompression to ambient pressures (see Section 3). researchers. For simplicity, the discussion can be separated into two end-member interpretations:

1) The shock metamorphic record in naturally shocked rocks is in conflict with experimental results obtained by the different types of experiments (Stöffler et al., 1991, 2018; Chen et al., 1996; Sharp and DeCarli, 2006; Gillet et al., 2007; El Goresy et al., 2013). Various researchers agree that there is a substantial difference between results from static pressure and dynamic (shock) pressure experiments, with different authors favoring results from either one or the other (Stöffler and Langenhorst, 1994; Sharp and DeCarli, 2006; Gillet et al., 2007; Kubo et al., 2010; Jaret et al., 2018; Sims et al., 2020). The argument is that static experiments are too slow and do not generate a shock wave, because the pressure increases stepwise and is sustained over relatively long time scales of seconds to minutes. The dynamic experiments occur over extremely short timescales $(\sim 1 \mathrm{~ns}-1 \mu \mathrm{s})$ and cannot sustain the shock conditions for the same duration as in a natural impact event. In the case of reverberation shock experiments, the maximum pressure is not achieved in a single shot as is the case in natural shock waves (Langenhorst, 2002). Thus, neither static 
nor dynamic experiments reproduce the duration and loading path as inferred for the natural case (Stöffler and Langenhorst, 1994; Sharp and DeCarli, 2006; Gillet et al., 2007), which is typically in the temporal range of milliseconds to rarely a few seconds (Langenhorst, 2002; Sims et al., 2019; Bowling et al., 2020). These interpretations are due to a well-discussed discrepancy between the pressures associated with transformations observed in static experiments compared to those in dynamic experiments. For example, diamond anvil cell (DAC) experiments and shock experiments from the same starting material show a 7-9 GPa difference in amorphization pressures (Jaret et al., 2018; Sims et al., 2020), consistent with interpretations compiled from literature of either isolated shock or static experiments (Daniel et al., 1997; Johnson et al., 2002a, 2003). Sims et al. (2020) recognized memory effects in the DAC experiments suggesting two amorphization points - one where the sample appears amorphous while still under compression, and a higher point where the sample remains amorphous after decompression. The higher pressure is closer to those of the shock experiments, which may in part help reconcile the discrepancies. Recent "rapid compression" experiments using membrane DAC setups that allow for control on strain-rate have shown that strain rate has a significant effect on the pressures at which plagioclase deforms (Sims et al., 2019).

2) The shock metamorphic record in naturally shocked rocks agrees with the results obtained by both shock and static pressure experiments (Fritz et al., 2017). Shock recovery experiments show that with increasing shock pressure different types of shock deformation effects develop in olivine and plagioclase, respectively. These two different thermo-barometers provide consistent results if studied in naturally shocked rocks such as shocked igneous Martian meteorites (Fritz et al., 2005a). These consistent results mean, that either both olivine and plagioclase are affected by potential differences between shock recovery experiments and the natural case to the same degree, or that shock recovery experiments accurately reproduce the conditions in a natural impact event. Shock reverberation experiments and hydrostatic pressure experiments produce an amorphous material from plagioclase and quartz as long as both types of experiments achieved the same pressure and temperature conditions and the samples are studied in a decompressed state (Fritz et al., 2019a). The shock-loading path achieved in shock 
reverberation experiments is a reasonable analog for the diffuse shock front traveling through lithological units composed of different types of minerals, porosity and fractures during a natural impact event (Fritz et al., 2011). Shock reverberation experiments allow well-defined shock pressures to be applied to a relatively large sample volume (Müller and Hornemann, 1969; Fritz et al., 2011). Most problems regarding the shock thermobarometry of meteorites are not related to experimental limitations but mainly result from inconsistent interpretation of the observational evidence (Fritz et al., 2017, 2019a). This includes: a) Misunderstandings regarding the duration of isobaric shock pressure conditions in naturally shocked rocks, which mostly implies that high-pressure phases form in (and near) local shock melt zones during declining shock pressures, b) A mineralogically inconsistent definition of the S6 shock level leading to an incorrect shock pressure assignment of all chondrites containing high-pressure phases (Fritz et al., 2017).

Reconciling the different interpretations of the shock thermo-barometry of rocks remains an ongoing area of active research and discussion. For example, a recent study of the shock stage distribution of 2280 ordinary chondrites confirmed that all S6 chondrites need reclassification (Bischoff et al., 2019). Despite these discussions, there is agreement on the types of shock deformation effects in feldspar and the order in which these shock effects occur with increasing pressure (see Section 3).

\section{Quantifying shock features in feldspars}

Multiple techniques have been applied to begin to quantify shock effects in feldspars. These techniques are summarized in Table 4, and discussed in the following sections.

\subsection{Measuring planar microstructures in feldspars}

In quartz, the number and orientation of PDF sets have been correlated with specific pressures through shock loading experiments allowing for refined pressure estimates from measurement of PDF orientations (e.g., Hörz, 1968; Huffman and Reimold, 1996; Ferrière et al., 
551 2009). Such a correlation has not been developed for feldspars due to the complexities involved

552 in PDF formation, identification, and orientation measurement in this mineral group.

The universal stage (U-stage) is the most common method of determining PDF

554 orientations in quartz, and this method has been used with feldspars, though it is significantly

555 more challenging (Stöffler, 1967; Dworak, 1969; Pittarello et al., 2020a). Measuring the

556 crystallographic orientation of any planar element in feldspars is complicated compared to

557 measuring the same features in quartz because feldspar is optically biaxial, and the crystal

558 structure (and therefore optical properties) of feldspars varies with composition through the solid

559 solution from Ca-rich to Na-rich to K-rich end members (Doeglas, 1940; Haff, 1940; Fairbairn

560 and Podolsky, 1951). Therefore in addition to the measurements themselves being complex,

561 accurately indexing the measured planes requires use of the specific indexing template for the

562 composition of feldspar under investigation; examples of such indexing templates can be found

563 in Stöffler (1967) and Dworak (1969). These factors result in orientation measurements of planar

564 features in feldspars using solely a U-stage to be both time-consuming and error-prone. For

565 example, Dworak (1969) measured 113 lamellae in 51 crystals of labradorite using the U-stage,

566 but due to the inherent difficulty in using a U-stage with feldspars, the lowered birefringence of

567 some host crystals, and the changes in An content (even within a single zoned crystal) the

568 assignment of the orientation of these lamellae had a large error. The most common PDF

569 orientations measured in feldspars are summarized in Table 5. Both Stöffler (1967) and

570 Robertson (1966) came to the conclusion that planar deformation features in feldspar form over

571 such a narrow range of pressures that it would not make sense to correlate orientations with peak

572 pressures. By implication, the mere presence of planar deformation features in feldspar,

573 regardless of their orientation, would be a sensitive shock barometer. 
An additional issue in investigating PDFs in feldspar with the U-stage is optimizing the

575 choice of glass hemispheres. The glass hemispheres each have a fixed refractive index, and for

576 accurate measurements the refractive index must be the same as the host crystal. However, the

577 refractive index of plagioclase ranges from 1.53 (albite) to 1.59 (anorthite) and for K-rich

578 feldspar, it ranges from 1.518 (orthoclase) and 1.539 (microcline). The hemispheres used for

579 measurements in quartz have refractive index 1.554, which is between the end member values

580 for plagioclase, but is too high for K-feldspar. Hemispheres with closer refractive indices exist,

581 but are not readily available to order and are difficult to match to the grain of interest. However,

582 the error induced by the difference in refractive index between the investigated grain and that of

583 the glass hemisphere pair can be calculated, and used to correct the data (e.g., Reinhard, 1931).

To circumvent some of the difficulties encountered by using the U-stage alone, EBSD

585 has recently been combined with U-stage or focused ion beam (FIB) milling and BSE imaging to

586 measure orientation of PDFs. EBSD provides crystal orientation of the host mineral

587 circumventing some of the challenges of defining a unique orientation to a biaxial mineral using

588 the U-stage alone. EBSD can also be used to determine a family of planes to which the trace of a

589 plane most likely belongs. However, to complete the orientation measurement in 3D, a "dip"

590 measurement is acquired using the U-stage (Pittarello and Koeberl, 2017; Pittarello et al., 2020a,

591 2020c) or by making a FIB trench perpendicular to the trace of the plane and measuring the dip

592 off the resultant image (Pickersgill and Lee, 2015). Thus far, using the FIB technique for this

593 purpose has been demonstrated only for quartz, however the same principle should work for

594 feldspars. Currently, transmission electron microscopy (TEM) is necessary for a definitive

595 identification of the crystallographic orientation along which PDFs develop in feldspar.

\section{5.2. Density, refractive index, and birefringence}


Density, refractive index (RI), and birefringence decrease as pressure increases until the

598 mineral becomes amorphous (Stöffler, 1974; Stöffler and Langenhorst, 1994). At shock

599 pressures $<20 \mathrm{GPa}$ the RI of shocked crystalline (birefringent) feldspar is only slightly lower

600 than the RI of unshocked feldspar (Kleeman, 1971; Stöffler, 1974; Robertson, 1975). At

601 pressures greater than $\sim 24$ to $35 \mathrm{GPa}$ (depending on chemical composition), feldspars are

602 completely converted to an amorphous state (diaplectic glass). Once this has occurred, and for

603 each type of feldspar over a very narrow pressure range, the RI of diaplectic feldspar glass drops

604 sharply (Ostertag, 1983). Shock pressures of $\sim 45 \mathrm{GPa}$ produce an amorphous material with a RI

605 matching that of a melt glass of identical chemical composition to feldspar. As an exception,

606 diaplectic anorthite glass produced in 41.5 GPa shock experiments displayed a RI that was

607 higher than that of unshocked crystalline anorthite (Fritz et al., 2019a). The well-tested

608 relationship between the refractive index of diaplectic feldspar glass, the An content, and the

609 shock pressure is illustrated in Figure 9 (e.g., Binns, 1967; Engelhardt et al., 1970; Stöffler et al.,

610 1975; Robertson, 1975; Ostertag, 1982; Fritz et al., 2019a).

\section{$611 \quad$ 5.3. X-Ray Diffraction (XRD)}

Two types of X-ray scattering experiments have been applied to shocked feldspars: X-ray

613 diffraction (XRD) experiments by powder or single-crystal XRD, in situ $\mu$ XRD (in thin section

614 and hand sample), and high-energy total X-ray scattering experiments using a synchrotron.

615 Contributions by total-scattering experiments are discussed in section 3 as they relate to amorphous phase studies. At pressures too low to induce amorphization or phase-change, XRD

617 patterns show peak broadening. There are two types of peak that can broaden in this fashion,

618 peaks in the chi direction (visible with single-crystal or $\mu$ XRD) and peaks in the $2 \theta$ direction

619 (visible with single-crystal, $\mu$ XRD, and powder diffraction). 
Shock experiments on andesine (4-10 GPa) and oligoclase (3-34 GPa) by Hörz and

621 Quaide (1973), showed that the degree of crystal lattice damage is correlated with shock

622 pressure. Furthermore, by using single crystal XRD to measure the length of streaks in the chi

623 direction (i.e., strain-related mosaicity) they could start to quantify the amount of strain recorded

624 by the crystals and use that as a proxy to quantify shock level. A correlation between streak

625 length and shock level was also documented in a single-crystal XRD study of plagioclase from

626 the Charlevoix impact structure (Walawender, 1977). Pickersgill et al. (2015a) built upon this

627 work by using in situ $\mu \mathrm{XRD}$ to quantify strain-related mosaicity by measuring the full width at

628 half maximum (FWHM) of the intensity vs. chi angle pattern, and compared those measurements

629 to optical signs of shock in samples of labradorite and andesine from the Mistastin Lake impact

630 structure, and lunar anorthite collected during the Apollo program. As with the single-crystal

631 studies discussed previously, peak broadening in the chi dimension increased with increased

632 optical signs of shock, up to amorphization of the sample (i.e., formation of diaplectic glass) - at

633 which point the X-rays produced a diffuse band on the detector. Powder XRD analyses of

634 shocked and unshocked sanidine by Kayama et al. (2012) reported almost no change in

635 diffraction peak intensity between samples. However, with increased shock pressure they did

636 find slight peak broadening in $2 \theta$, followed by a sudden change to no detectable peaks (i.e., an

637 amorphous pattern) for amorphous samples.

Strain-related mosaicity, as measured using in situ $\mu \mathrm{XRD}$ or single-crystal XRD, shows

639 more variation in shock level of feldspars prior to amorphization than optical determinations, and

640 likely could be useful in subdividing the lower end of the shock scale (Pickersgill et al., 2015a).

641 However, in order to properly quantify shock via strain-related mosaicity, more work needs to be 642 done such as correlating results with those from other techniques (Raman for example) and via 
643 application to a wider variety of feldspar compositions and, ideally, also to experimentally

644 shocked samples. Caution must be applied when using XRD to measure shock, as the features

645 described in the previous paragraphs indicate strain, and therefore, without contextual

646 information, it is impossible to differentiate the cause of the strain (i.e., shock or tectonism).

\section{5.4. Thermal Infrared Absorption Spectroscopy} and less spectral detail than unshocked feldspar. Both detail and intensity continue to decrease as pressure increases as a result of increased glass content and progressive lattice disordering

651 (Lyon, 1963; Bunch et al., 1967; Stöffler and Hornemann, 1972; Stöffler, 1974; Arndt et al., 652 1982; Ostertag, 1983; Johnson et al., 2002b, 2003; Jaret et al., 2015, 2018). Crystalline feldspars 653 exhibit infrared reflectance peaks between 950 and $1150 \mathrm{~cm}^{-1}$ (reststrahlen bands) that 654 correspond to $\mathrm{Si}-\mathrm{O}$ stretching modes of the $\mathrm{SiO}_{4}$ tetrahedra. Additional peaks occur between 700 655 and $850 \mathrm{~cm}^{-1}$ corresponding to Si-bridging oxygen modes, and between 400 and $600 \mathrm{~cm}^{-1}$

656 corresponding to O-Si-O bending modes (Iiishi et al., 1971; Okuno, 2003). Bulk IR emissivity of 657 experimentally shocked albite shows a progression of change to the IR spectra in the form of 658 decrease in overall band intensity relative to background, as well as loss of the low wavenumber 659 peaks. Spectroscopically, plagioclase that has been transformed to amorphous material (either 660 by melting or as diaplectic glass) exhibits one broad peak reflecting the Si-O stretching vibration. Micro-FTIR spectroscopy of individual plagioclase grains, both naturally and 662 experimentally shocked, has an added complexity in that infrared spectra are orientation663 sensitive, where peak positions and intensities of vibrational modes in plagioclase can shift by $664 \sim 40$ wavenumbers, depending on orientation, making it difficult to correlate changes in peak 665 intensities or positions with shock level (Fig. 9). However, the degree to which orientation 
666 affects the spectra decreases with increasing shock level (Jaret et al., 2018). Furthermore,

667 orientation effects have been found to be a useful tool for distinguishing between diaplectic and

668 melt-produced glasses. Diaplectic glass retains orientation effects in IR, despite its amorphous

669 nature. Melt glass on the other hand does not show effects of orientation on spectral position.

\section{5.5. Cathodoluminescence (CL)}

The main effects of shock metamorphism on cathodoluminescence (CL) spectra of

672 plagioclase are 1) decreasing luminescence with increasing amorphization (e.g., Fig. 12, Kaus

673 and Bischoff, 2000; Götte, 2009; Götze, 2009; Pittarello et al., 2015; Kayama et al., 2018;

674 Pittarello et al., 2020b); 2) the normal band emission at $\sim 550-570 \mathrm{~nm}$ is often shifted to $\sim 630$

$675 \mathrm{~nm}$ (Kayama et al., 2009a); 3) diaplectic plagioclase glass produces a broad band around $350 \mathrm{~nm}$

676 (Götte, 2009; Pittarello et al., 2015; Gucsik et al., 2004). Intriguingly, and in contrast to

677 plagioclase, alkali feldspar shows increased CL intensity with increasing shock pressure

678 (Kayama et al., 2012).

CL spectral analysis has been proposed to quantify shock effects and correlate with pressure (e.g., Kayama et al., 2012, 2018). However, the correlation between shock and signal

681 intensity is complex because the intensity of the luminescent centers is regulated by numerous 682 variables, including the abundance of activators, which can be trace elements, point defects, or 683 both, and the abundance of quenchers, which would reduce the effect of the activators. Even in 684 unshocked feldspars, the nature of activators is not always clear, so imaging studies must be 685 accompanied by detailed back-scattered electron imaging in order to properly interpret the 686 microstructures (e.g., Finch and Klein, 1999; Götze et al., 2000; Parsons et al., 2015). As a result 687 of the complex mechanisms involved in luminescence, and therefore the relationship between 688 luminescence and shock intensity, CL is generally viewed as less reliable than other techniques 
689 (e.g., XRD or Raman) for quantifying shock intensity, though it remains one of the most useful

690 tools for investigating microstructures.

\section{$691 \quad$ 5.6. Raman spectroscopy}

693 spectra show that increased shock corresponds to a progressive decrease in peak intensity and 694 increase in peak width compared to unshocked feldspar (Fig. 13, e.g., Fritz et al., 2005b; Jaret et 695 al., 2014). Peak positions and width are somewhat dependent on composition, so it is challenging to identify quantitative metrics in Raman spectra that uniquely identify shock.

At pressures $<29 \mathrm{GPa}$, shocked plagioclase has lower intensity and broader FWHM of

698 characteristic Raman bands compared to unshocked plagioclase. At higher pressure ( $>\sim 40 \mathrm{GPa})$

699 Raman spectra exhibit a broad plateau as a result of amorphization (Fig. 13, Jaret et al., 2018). At

700 much higher pressure (>45 GPa) high post-shock temperatures lead to recrystallization, and

701 reappearance of the characteristic Raman spectra (Fritz et al., 2005a,b).

\subsection{Photoluminescence spectroscopy}

Photoluminescence spectroscopy is a technique, complementary to Raman spectroscopy,

704 which has only been applied to shocked plagioclase by Pittarello et al. (2020b).

705 Photoluminescence allows quantification of the "damage" in the lattice (i.e., amorphization) as

706 percent of disordered structure within the investigated volume (a few $\mu \mathrm{m}^{3}$ ). Similar to peak

707 broadening in Raman spectra, $\mathrm{Nd}^{3+}$ luminescence bands get wider and are less defined with 708 increased levels of amorphization.

\subsection{Nuclear Magnetic Resonance (NMR) Spectroscopy}


NMR spectroscopy uses nuclear spin transitions as a measure of the local chemical

711 bonding and coordination environment (Stebbins and Xue, 2014). Because NMR is sensitive to

712 the entire local chemical environment and not just long-range ordering, NMR is particularly

713 useful for measuring the structure of amorphous materials. In amorphous silicates, NMR spectra

714 of ${ }^{29} \mathrm{Si}\left({ }^{\left({ }^{29}\right.} \mathrm{Si} \mathrm{NMR}\right)$ are sensitive to the number and length of Si-O bonds, types of nearest

715 neighbor atoms, and coordination of $\mathrm{Si}$ - all of which can change during shock deformation or if

716 high-pressure phases are produced (Jaret et al., 2015).

\section{6. Ongoing debates}

\section{6.1. Formation mechanism of diaplectic glass}

The details of diaplectic glass formation are the subject of much debate. There are, in

720 general, two main hypotheses: 1) rapid quenching of monomineralic melt at high pressure, or 2)

721 solid-state structural collapse/destruction of atomic ordering of the mineral. Some details of these

722 two formation hypotheses are explained here.

\section{6.1.1. Melt formation}

Grady (1977) interpreted diaplectic glass to form by quenching of a high-density melt

725 phase upon pressure release. Such a phase would have solidified so rapidly that flow, which

726 would normally erase the morphology and texture of the precursor minerals, did not have time to

727 occur. In this scenario, local temperature spikes due to heterogeneous shock compression, cause

728 local melting despite the temperature in the majority of the rock remaining below the liquidus

729 (Grady et al., 1975; Grady, 1980). A key aspect of Grady's scenario for formation of diaplectic

730 glass is the dissipation of strain energy by the development of shear bands. Microstructures

731 similar to shear bands have been observed in recovered samples from rapid compression 
732 experiments (Sims et al., 2019). Similarly, Arndt et al. (1982) suggested that diaplectic glass

733 forms from shock-induced melting, but that the duration of high temperature is short enough that

734 the liquid transition is incomplete and the disordered transitional state is 'locked in'. Stöffler and

735 Langenhorst (1994) explained the formation of diaplectic quartz glass by shock melting and

736 quenching during decompression. The concept of diaplectic glass being a high-pressure melt was

737 later adopted to explain the formation of maskelynite by Chen and El Goresy (2000) and El

738 Goresy et al. (2013).

\section{6.1.2. Solid state formation}

The amorphous structure, and absence of flow textures, suggests a near instantaneous

741 change from a crystalline structure to glass without melting (e.g., De Carli and Jamieson, 1959;

742 Engelhardt and Stöffler, 1968). Ahrens et al. (1969) used shock experiments on plagioclase to

743 suggest that diaplectic glass forms by solid-state release from a high-pressure phase during

744 decompression. Williams and Jeanloz (1988) also favored a scenario where diaplectic glass is

745 produced by reversion from a higher-pressure phase, which, similar to the scenario of Hemley et

746 al. (1988), calls for high pressure-induced high-coordinated glasses. Hemley et al.'s assumption

747 of a high-coordinated phase during shock compression rests on the experimentally determined

748 Hugoniot curve where the steeper high-pressure branch (region III in Fig. 2) indicates a density

749 during shock compression similar to the density expected of a compressed hollandite-like

750 structured phase (Ahrens et al., 1969). A hollandite-like structure scenario would be supported

751 by the existence of high-pressure phases and/or high-coordinated glasses. However, evidence of

752 high-pressure phases was not observed in static experimentally produced diaplectic glass (Daniel

753 et al., 1997; Sims et al., 2020). Likewise, high-coordinated glasses were not observed in in situ

754 compression experiments or naturally shocked samples (Kubo et al., 2010; Jaret et al., 2015; 
755 Sims et al., 2019). Furthermore, recent ${ }^{29} \mathrm{Si}$ NMR studies of natural diaplectic plagioclase, did 756 not detect structural remnants of high-pressure high-coordination glass, even though such

757 remnants would be resolvable with NMR analyses (Jaret et al., 2015). Ashworth and Schneider

758 (1985) proposed a mechanism for diaplectic $\mathrm{SiO}_{2}$ glass that is similar to metamictization - a

759 process in which alpha particles physically displace atoms within the unit cell. In a diaplectic

760 glass, physical displacement of atoms would be caused by the shock wave, rather than alpha 761 particles.

Shock recovery experiments at starting temperatures of $77-293 \mathrm{~K}$ showed that in this

763 temperature range the formation of diaplectic plagioclase glass is controlled by shock pressure

764 only, and not temperature (Fritz et al., 2019a). This observation, together with the structural

765 properties of diaplectic plagioclase glass (Jaret et al., 2015) and the recognition that diaplectic

766 glass forms via a gradual collapse of the lattice (Hörz and Quaide, 1973, Fritz et al., 2019a), and

767 the observation of isotropic twins alternating with crystalline twins in plagioclase (e.g., Stöffler,

768 1971; Pickersgill et al., 2015a,b; Pittarello et al., 2020a) further advocates for a solid-state

769 amorphization mechanism.

\section{$770 \quad$ 6.2. Maskelynite and diaplectic glass}

The first description of maskelynite was by Tschermak (1872) in the Shergotty martian

772 meteorite, described as a previously unrecognised isotropic phase of near labradorite

773 composition. This new phase was then named after M. H. N. Story-Maskelyne, a famous English

774 mineralogist of the time. Tschermak (1883) then found the same phase in chondrites and, upon

775 realizing that it was pseudomorphous with plagioclase, changed his interpretation to a melted or

776 otherwise vitrified glass of plagioclase composition. A shock origin for maskelynite was

777 suggested by Binns (1967) based on differences in the RI of maskelynite and melt-glass. At the 
778 same time, the term diaplectic glass was proposed to refer to "amorphous phases produced by

779 shock waves without melting, and [which] are distinguishable from ordinary molten glasses"

780 (Engelhardt et al., 1967; and Engelhardt and Stöffler, 1968). Since that time, maskelynite and

781 diaplectic plagioclase glass have often been used interchangeably, which attached a genetic

782 connotation to maskelynite. Historically, most isotropic plagioclase-composition material was

783 called maskelynite, but modern observations have enabled us to distinguish between phases that

784 have flowed (e.g., Chen and El Goresy, 2000) and "true" diaplectic glasses that show no

785 evidence of melting (e.g., Jaret et al., 2015, Diemann and Arndt, 1984), even within a single thin

786 section. Because there is confusion over how the term maskelynite is interpreted, it is imperative

787 that clear observations regarding the nature of the isotropic phase be included in any description

788 so that it is clear whether the authors are using "maskelynite" to refer to an apparently solid-state 789 glass or a melt product.

\section{Concluding remarks \& remaining questions}

Feldspars are typically difficult to study due to the optical complexity of their crystal

792 structure and, when in the presence of water, their relatively rapid weathering rate.

793 Consequently, the feldspar group is often neglected in favor of quartz or olivine for use in shock

794 barometry. As a result, the shock scale for feldspar is limited and, essentially, qualitative.

795 However, feldspars will have particular utility when studying quartz-poor rocks such as basalt, a

796 dominant rock type on Mars and Earth's moon, and an important surficial lithology on most

797 terrestrial bodies. There have been many advances on the effects of shock metamorphism on

798 feldspars over the past five decades but there are several major questions remain open, in

799 particular: 
1. Determining the exact nature and formation mechanism of diaplectic glass. Recent work has made significant strides, but confirmation and further studies would help to bolster these results (Section 6.1);

2. Understanding the formation of PDFs in feldspars, including exactly why the An content appears to be a controlling factor; the relationship between thin closely spaced shockinduced microtwins and PDFs; whether FFs form in feldspars; and the development of apparently shock-induced planar features that do not appear to be strict PDFs when investigated using high resolution TEM and EBSD (Section 3.4);

3. Whether or not measuring the crystallographic orientations of shock-induced planar features in feldspars can be improved upon and developed into a useful tool for shock barometry (Section 5.1);

4. Understanding the exact mechanism by which only alternate twins deform in polysynthetically twinned plagioclase, leaving the other set apparently undamaged, and whether this could be used to determine the local orientation of shock wave propagation (Section 3.6);

5. How, or if, the intensity of shock effects is affected by the presence of pre-existing microstructures (e.g., cleavage, twinning, exsolution), the crystallographic orientation with respect to the shock wave, and the presence of other mineral phases (Sections 3.4, $3.6)$

6. How best to utilize and integrate multiple analytical techniques, which probe slightly different aspects of feldspar composition/structure and deformation (Section 5); 
7. How to reconcile the pressure conditions associated with crystallographic transformations between various experimental techniques and naturally shocked materials, which is an ongoing challenge in many fields of geoscience: do all types of minerals behave in the same way during shock recovery experiments and natural impacts or do some mineral develop the same shock effects at lower pressures? (Section 4)

8. How does shock influence radioisotopic age determination? A topic not touched upon in this paper, because it is worth an entire volume on its own, but the interested reader can examine, for example, Jessberger and Ostertag (1982) and Fernandes et al. (2009).

830 importance of understanding their shock behavior and ability to inform shock barometry will 831 only become more relevant as we gain increasing numbers of samples from other planetary 832 bodies.

\section{ACKNOWLEDGMENTS}

AEP is supported by the Leverhulme Trust Research Project Grant number RPG-2018-

835 061. LP was supported by the Austrian Science Fund (FWF), project number V505-N29. JF

836 thanks Vera Assis Fernandes and Ansgar Greshake for intense cooperation regarding the shock

837 metamorphic record in meteorites and products of experiments. We thank E. L. Walton and J. G.

838 Spray for thorough and helpful reviews.

\section{REFERENCES CITED} pressure plagioclase polymorph at mineral interfaces in doleritic rock of the Lockne impact structure (Sweden): Scientific Reports, v. 6, p. 25991, doi:10.1038/srep25991. 
Ahrens, T.J., Petersen, C.F., and Rosenberg, J.T., 1969, Shock compression of feldspars: Journal of Geophysical Research, v. 74, p. 2727-2746.

Ahrens, T.J., O'Keefe, J.D., and Gibbons, R. V, 1973, Shock compression of a recrystallized anorthositic rock from Apollo 15*: Proceedings of the 4th Lunar Science Conference, v. 3, p. $2575-2590$.

Angel, R., 1988, High-pressure structure of anorthite: The American mineralogist, v. 73, p. 1114-1119.

Angel, R.J., 1994, Feldspars at High Pressure BT - Feldspars and their Reactions, in Parsons, I. ed., Dordrecht, Springer Netherlands, p. 271-312, doi:10.1007/978-94-011-1106-5_7.

Arndt, J., Hummel, W., and Gonzalez-Cabeza, I., 1982, Diaplectic labradorite glass from the Manicouagan impact crater; I, Physical properties, crystallization, structural and genetic implications: Physics and Chemistry of Minerals, v. 8, p. 230-239.

Ashworth, J.R., and Schneider, H., 1985, Deformation and transformation in experimentally shock-loaded quartz: Physics and Chemistry of Minerals, v. 11, p. 241-249, doi:10.1007/BF00307401.

Beck, P., Gillet, P., Gautron, L., Daniel, I., and El Goresy, A., 2004, A new natural high-pressure $(\mathrm{Na}, \mathrm{Ca})$-hexaluminosilicate [(CaxNa1-x)Al3 $+\mathrm{xSi3}-\mathrm{xO} 11]$ in shocked Martian meteorites: Earth and Planetary Science Letters, v. 219, p. 1-12, doi.org/10.1016/S0012821X(03)00695-2.

Binns, R.A., 1967, Stony meteorites bearing maskelynite: Nature, v. 213, p. 1111-1112.

Bischoff, A., and Stöffler, D., 1984, Chemical and structural changes induced by thermal annealing of shocked feldspar inclusions in impact melt rocks from Lappajaervi Crater, Finland (W. V Boynton \& G. Schubert, Eds.): Journal of Geophysical Research, v. 89, Suppl., p. 645-656, doi:http://dx.doi.org/10.1029/JB089iS02p0B645.

Bischoff, A., Schleiting, M., and Patzek, M., 2019, Shock stage distribution of 2280 ordinary chondrites - Can bulk chondrites with a shock stage of S6 exist as individual rocks? Meteoritics and Planetary Science, v. 54, p. 2189-2202, doi:10.1111/maps.13208.

Bowling, T.J., Johnson, B.C., Wiggins, S.E., Walton, E.L. , Melosh, H.J. Sharp, T.G., 2020, Dwell time at high pressure of meteorites during impact ejection from Mars: Icarus, 343, 113689, doi.org/10.1016/j.icarus.2020.113689.

Bunch, T.E., Cohen, A.J., and Dence, M.R., 1967, Natural terrestrial maskelynite: American Mineralogist, v. 52, p. 244-253.

Chen, M., and El Goresy, A., 2000, The nature of maskelynite in shocked meteorites; not diaplectic glass but a glass quenched from shock-induced dense melt at high pressures: Earth and Planetary Science Letters, v. 179, p. 489-502. 
Chen, M., Sharp, T.G., El Goresy, A., Wopenka, B., and Xie, X., 1996, The majorite-pyrope + magnesiowüstite assemblage: Constraints on the history of shock veins in chondrites: Science, v. 271, p. 1570-1573, doi:10.1126/science.271.5255.1570.

Dachille, F., Gigl, P., and Simons, P.Y., 1968, Experimental and analytical studies of crystalline damage useful for the recognition of impact structures, in French, B.M. and Short, N.M. eds., Shock metamorphism of natural materials, Baltimore, MD, Mono Book Corp., p. $555-570$.

Daniel, I., Gillet, P., McMillan, P.F., Wolf, G., and Verhelst, M.A., 1997, High-pressure behavior of anorthite: Compression and amorphization: Journal of Geophysical Research: Solid Earth, v. 102, p. 10313-10325, doi:10.1029/97jb00398.

Davison, T. M., Collins, G. S., and Ciesla, F. J., 2010, Numerical modelling of heating in porous planetesimal collisions: Icarus, v. 208, p. 468-481.

De Carli, P.S., and Jamieson, J.C., 1959, Formation of an amorphous form of quartz under shock conditions: The Journal of Chemical Physics, v. 31, p. 1675-1676, doi:10.1063/1.1730673.

Deer, W.A., Howie, R.A., and Zussman, J., 2001, Rock-forming minerals, Volume 4a: Framework silicates - Feldspars: London, The Geological Society, 972 p.

Dence, M. R., Douglas, J. A. V., Plant, A. G., and Traill, R. J., 1970, Petrology, Mineralogy, and deformation of Apollo 11 samples: Proceedings of the Apollo 11 Lunar Science Conference, v. 1, p 315-340.

Diemann, E., and Arndt, J., 1984, Diaplectic Labradorite Glass from the Manicouagan Impact Crater: II. X-Ray Diffraction Studies and Structural Model: Physics and Chemistry of Minerals, v. 11, p. 178-181.

Doeglas, D.J., 1940, Reliable and rapid method for distinguishing quartz and untwinned feldspar with the universal stage: American Mineralogist, v. 25, p. 286.

Dressler, B., 1990, Shock metamorphic features and their zoning and orientation in the Precambrian rocks of the Manicouagan Structure, Quebec, Canada: Tectonophysics, v. 171, p. 229-245, doi:10.1016/0040-1951(90)90101-D.

Dworak, U., 1969, Stoßwellenmetamorphose des Anorthosits vom Manicouagan Krater, Quebec, Canada: Contributions to Mineralogy and Petrology, v. 24, p. 306-347.

El Goresy, A., Chen, M., Gillet, P., and Dubrovinsky, L.S., 2000, Shock-induced high-pressure phase-transition of labradorite to hollandite "(Na47-Ca51-K2)" in Zagami and the assemblage hollandite "(Na80-Ca12-K8)" + jadeite in L chondrites: constraints to peakshock pressures (D. W. G. Sears et al., Eds.): Meteoritics \& Planetary Science, v. 35, p. A51-A51.

El Goresy, A., Gillet, P., Miyahara, M., Ohtani, E., Ozawa, S., Beck, P., and Montagnac, G., 2013, Shock-induced deformation of Shergottites: Shock-pressures and perturbations of 
magmatic ages on Mars: Geochimica et Cosmochimica Acta, v. 101, p. 233-262, doi:10.1016/j.gca.2012.10.002.

Engelhardt, W. von, and Bertsch, W., 1969, Shock induced planar deformation structures in quartz from the ries crater, Germany: Contributions to Mineralogy and Petrology, v. 21, p. 378, doi:10.1007/BF02672809.

Engelhardt, W. von, and Stöffler, D., 1968, Stages of shock metamorphism in crystalline rocks of the Ries Basin, Germany., in French, B.M. and Short, N.M. eds., Shock metamorphism of natural materials, Baltimore, MD, Mono Book Corp., p. 159-168.

Engelhardt, W. von, Arndt, J., Stöffler, D., Muller, W.F., Jeziorkowski, H., and Gubser, R., 1967, Diaplektische Gläser in den Breccien des Ries yon Nördlingen als Anzeichen für Stosswellenmetamorphose: Contributions to Mineralogy and Petrology, v. 15, p. 93-102.

Engelhardt, W. von, Arndt, J., Mueller, W.F., and Stöffler, D., 1970, Shock metamorphism of lunar rocks and origin of the regolith at the Apollo 11 landing site: Proceedings of the Apollo 11 Lunar Science Conference, v. 1, p. 363-384.

Evans, W.J., Yoo, C.S., Lee, G.W., Cynn, H., Lipp, M.J., and Visbeck, K., 2007, Dynamic diamond anvil cell (dDAC): A novel device for studying the dynamic-pressure properties of materials: Review of Scientific Instruments, v. 78, doi:10.1063/1.2751409.

Fairbairn, H.W., and Podolsky, T., 1951, Notes on precision and accuracy of optic angle determination with the universal stage: American Mineralogist, v. 36, p. 823.

Fernandes, V.A., Burgess, R., and Morris, A., 2009, ${ }^{40} \mathrm{Ar}-{ }^{39} \mathrm{Ar}$ age determinations of lunar basalt meteorites Asuka 881757, Yamato 793169, Miller Range 05035, LaPaz Icefield 02205, Northwest Africa 479, and basaltic breccia Elephant Moraine 96008: Meteoritics \& Planetary Science, v. 44, p. 805-821. doi.org/10.1111/j.1945-5100.2009.tb00770.x.

Ferrière, L., and Osinski, G.R., 2013, Shock Metamorphism, in Osinski, G.R. and Pierazzo, E. eds., Impact Cratering: Processes and Products, Wiley-Blackwell, p. 106-124.

Ferrière, L., Morrow, J.R., Amgaa, T., and Koeberl, C., 2009, Systematic study of universalstage measurements of planar deformation features in shocked quartz: Implications for statistical significance and representation of results: Meteoritics \& Planetary Science, v. 44, p. 925-940.

Ferrière, L., Koeberl, C., Libowitzky, E., Reimold, W.U., Greshake, A., and Brandstätter, F., 2010, Ballen quartz and cristobalite in impactites: New investigations, in Gibson, R.L. and Reimold, W.U. eds., Large Meteorite Impacts and Planetary Evolution IV, Geological Society of America, v. 465, p. 0, doi:10.1130/2010.2465(29).

Finch, A.A., and Klein, J., 1999, The causes and petrological significance of cathodoluminescence emissions from alkali feldspars: Contributions to Mineralogy and Petrology, v. 135, p. 234-243, doi:10.1007/s004100050509. 
Flemming, R.L., 2007, Micro X-ray diffraction ( $\mu$ XRD); a versatile technique for charcterization of Earth and planetary materials: Canadian Journal of Earth Sciences, v. 44, p. 1333-1346.

952

953

954

955

956

957

958

959

960

961

962

963

964

965

966

967

968

969

970

971

972

973

974

975

976

977

978

979

980

981

982

983

984

985

French, B.M., 1968, Sudbury structure, Ontario: Some petrographic evidence for an origin by meteorite impact, in French, B.M. and Short, N.M. eds., Shock metamorphism of natural materials, Baltimore, Mono Book Corp., p. 383-411.

French, B.M., 1998, Traces of catastrophe, a handbook of shock-metamorphic effects in terrestrial meteorite impact structures: Houston, TX, USA, Lunar and Planetary Institute, $120 \mathrm{p}$.

French, B.M., and Koeberl, C., 2010, The convincing identification of terrestrial meteorite impact structures: What works, what doesn't, and why: Earth-Science Reviews, v. 98, p. 123-170, doi:10.1016/j.earscirev.2009.10.009.

French, B.M., and Short, N.M. (ed)., 1968, Shock metamorphism of natural materials (B. M. French \& N. M. Short, Eds.): Baltimore, Mono Book Corp., 644 p.

French, B., Hartung, J., Short, N., and Dietz, R., 1970, Tenoumer Crater, Mauritania. Age and petrologic evidence for origin by meteorite impact: Journal of Geophysical Research, v. 75, p. 4396-4406, doi:10.1029/jb075i023p04396.

French, B.M., Koeberl, C., Gilmour, I., Shirey, S.B., Dons, J.A., and Naterstad, J., 1997, The Gardnos impact structure, Norway: Petrology and geochemistry of target rocks and impactites: Geochimica et Cosmochimica Acta, v. 61, p. 873-904, doi:10.1016/S00167037(96)00382-1.

French, B. M., Cordua, W. S., and Plescia, J. B., 2004, The Rock Elm meteorite impact structure, Wisconsin: Geology and shock-metamorphic effects in quartz: GSA Bulletin, v. 116, p. 200-218.

Fritz, J., Greshake, A., and Stöffler, D., 2005a, Micro-Raman spectroscopy of plagioclase and maskelynite in Martian meteorites: Evidence of progressive shock metamorphism: Antarctic Meteorite Research, v. 18, p. 96-116.

Fritz J., Artemieva N. A., and Greshake A., 2005b, Ejection of Martian meteorites: Meteoritics \& Planetary Science, v. 40, p. 1393-1411.

Fritz, J., Wünnemann, K., Reimold, W.U., Meyer, C., and Hornemann, U., 2011, Shock experiments on quartz targets pre-cooled to $77 \mathrm{~K}$ : International Journal of Impact Engineering, v. 38, p. 440-445, doi:10.1016/j.ijimpeng.2010.10.014.

Fritz, J., Greshake, A., and Fernandes, V.A., 2017, Revising the shock classification of meteorites: Meteoritics and Planetary Science, v. 52, p. 1216-1232, doi:10.1111/maps.12845.

Fritz, J., Assis Fernandes, V., Greshake, A., Holzwarth, A., and Böttger, U., 2019a, On the formation of diaplectic glass: Shock and thermal experiments with plagioclase of different 
chemical compositions: Meteoritics and Planetary Science, v. 54, p. 1533-1547, doi:10.1111/maps.13289.

Fritz, J., Greshake, A., Klementova, M., Wirth, R., Palatinus, L., Assis Fernandes, V., Bottger, U., and Ferriere, L., 2019b, Donwilhelmsite, IMA 2018-113. . CNMNC Newsletter No. 47, February 2019, page 199: European Journal of Mineralogy, v. 31, p. 197-202.

Gibbons, R., and Ahrens, T., 1977, Effects of shock pressures on calcic plagioclase: Physics and Chemistry of Minerals, v. 1, p. 95-107.

Gibson, R.L., and Reimold, W.U., 2005, Shock pressure distribution in the Vredefort impact structure, South Africa, in Kenkmann, T., Hörz, F.P., and Deutsch, A. eds., Special Paper Geological Society of America, Geological Society of America (GSA), Boulder, CO, v. 384, p. 329-349.

Gillet, P., Chen, M., Dubrovinsky, L., and El Goresy, A., 2000, Natural NaAlSi $\mathrm{O}_{8}$-hollandite in the shocked sixiangkou meteorite: Science (New York, N.Y.), v. 287, p. 1633-6.

Gillet, P., El Goresy, A., Beck, P., and Chen, M., 2007, High-pressure mineral assemblages in shocked meteorites and shocked terrestrial rocks: Mechanisms of phase transformations and constraints to pressure and temperature histories, in Ohtani, E. ed., Advances in HighPressure Mineralogy, Geological Society of America, v. 421, p. 0, doi:10.1130/2007.2421(05).

Götte, T., 2009, Petrological modifications in continental target rocks from terrestrial impact structures: evidence from cathodoluminescence, in Gucsik, A. ed., Cathodoluminescence and its application in the planetary sciences, Heidelberg, Springer-Verlag, p. 45-60.

Götze, J., 2009, Cathodoluminescence microscopy and spectroscopy of lunar rocks and minerals BT - Cathodoluminescence and its application in the planetary sciences, in Gucsik, A. ed., Berlin, Heidelberg, Springer Berlin Heidelberg, p. 87-110, doi:10.1007/978-3-540-875291 5.

Götze, J., and Kempe, U., 2009, Physical principles of cathodoluminescence (CL) and its applications in geosciences, in Gucsik, A. ed., Physical principles of Cathodoluminescence (CL) and its applications in geosciences, Berlin, Springer-Verlag, p. 1-22.

Götze, J., Krbetschek, M.R., Habermann, D., and Wolf, D., 2000, High-resolution cathodoluminescence studies of feldspar minerals BT - Cathodoluminescence in geosciences, in Pagel, M., Barbin, V., Blanc, P., and Ohnenstetter, D. eds., Berlin, Heidelberg, Springer Berlin Heidelberg, p. 245-270, doi:10.1007/978-3-662-04086-7_10.

Grady, D.E., 1977, Processes occurring in shock wave compression of rocks and minerals, in Manghnani, M.H. and Akimoto, S.I. eds., High-pressure research: Applications in Geophysics, New York, Academic Press, p. 389-438.

Grady, D.E., 1980, Shock deformation of brittle solids: Journal of Geophysical Research, v. 85, p. 913-924, doi:http://dx.doi.org/10.1029/JB085iB02p00913. 
1023 Grady, D.E., and Murri, W.J., 1976, Dynamic unloading in shock compressed feldspar: Geophysical Research Letters, v. 3, p. 472-474.

1025 Grady, D.E., Murri, W.J., and De Carli, P.S., 1975, Hugoniot sound velocities and phase transformations in two silicates: Journal of Geophysical Research, v. 80, p. 4857-4861, doi:http://dx.doi.org/10.1029/JB080i035p04857.

1028

1029

1030

1031

1032

1033

1034

1035

1036

1037

1038

1039

1040

1041

1042

1043

1044

1045

1046

1047

1048

1049

1050

1051

1052

1053

1054

1055

1056

1057

1058

1059
Gratz, A.J., Nellis, W.J., Christie, J.M., Brocious, W., Swegle, J., and Cordier, P., 1992, Shock metamorphism of quartz with initial temperatures -170 to $+1000^{\circ} \mathrm{C}$ : Physics and Chemistry of Minerals, v. 19, p. 267-288, doi:10.1007/BF00204005.

Grieve, R.A.F., 1975, Petrology and chemistry of the impact melt at Mistastin Lake crater, Labrador: Geological Society of America Bulletin, v. 86, p. 1617-1629.

Gucsik, A., Ninagawa, K., Nishido, H., Toyoda, S., Tsuchiyama, A., Bidló, A., and Brezsnyánszky, K., 2004, Cathodoluminescence (CL) spectral study of experimentally shock-deformed plagioclase, in Workshop on Chondrites and Protoplanetary Disk, Houston, TX, United States (USA), Lunar and Planetary Institute, Houston, TX, p. Abstract \#9012.

Haff, J.C., 1940, Use of the Wulff net in mineral determination with the Universal stage: American Mineralogist, v. 24, p. 689-707.

Harris, R., Schultz, P., and Jaret, S., 2019, Critical comparison of textures observed in impact melt and volcanic rocks: Geological Society of America Abstracts with Programs, doi:10.1130/abs/2019AM-338073.

Hemley, R.J., Jephcoat, A.P., Mao, H.K., Ming, L.C., and Manghnani, M.H., 1988, Pressureinduced amorphization of crystalline silica: Nature, v. 334, p. 52-54, doi: $10.1038 / 334052 \mathrm{a} 0$.

Hörz, F., 1968, Statistical measurements of deformation structures and refractive indices in experimentally shock loaded quartz, in French, B.M. and Short, N.M. eds., Shock metamorphism of natural materials, Baltimore, MD, Mono Book Corp., p. 243-253.

Hörz, F., and Quaide, W.L., 1973, Debye-Scherrer investigations of experimentally shocked silicates: The Moon, v. 6, p. 45-82.

Huffman, A.R., and Reimold, W.U., 1996, Experimental constraints on shock-induced microstructures in naturally deformed silicates: Tectonophysics, v. 256, p. 165-217, doi:10.1016/0040-1951(95)00162-x.

Huffman, A.R., Brown, J.M., Carter, N.L., and Reimold, W.U., 1993, The microstructural response of quartz and feldspar under shock loading at variable temperatures: Journal of Geophysical Research, v. 98, p. 22171-22197, doi:10.1029/93JB01425.

Iiishi, K.T., Tomisaka, T., Kato, T., and Umegaki, Y., 1971, Isomorphous substitution and infrared and far infrared spectra of the feldspar group: Neues Jahrbuch fuer Mineralogie. Abhandlungen, v. 115, p. 98-119. 
1060

1061

1062

1063

1064

1065

1066

1067

1068

1069

1070

1071

1072

1073

1074

1075

1076

1077

1078

1079

1080

1081

1082

1083

1084

1085

1086

1087

1088

1089

1090

1091

1092

1093

1094

1095
Irifune, T., Ringwood, A. E., and Hibberson, W. O., 1994, Subduction of continental crust and terrigenous and pelagic sediments: an experimental study: Earth and Planetary Science Letters, v. 126, p. 351-368.

James, O.B., 1969, Jadeite: Shock-induced formation from oligoclase, Ries Crater, Germany: Science, v. 165, p. 1005 LP - 1008, doi:10.1126/science.165.3897.1005.

Janssen, C., Wirth, R., Rybacki, E., Naumann, R., Kemnitz, H., Wenk, H.-R., and Dresen, G., 2010, Amorphous material in SAFOD core samples (San Andreas Fault): Evidence for crush-origin pseudotachylytes? Geophysical Research Letters, v. 37, doi:10.1029/2009GL040993.

Jaret, S.J., Kah, L.C., and Harris, R.S., 2014, Progressive deformation of feldspar recording lowbarometry impact processes, Tenoumer impact structure, Mauritania: Meteoritics \& Planetary Science, v. 49, p. 1007-1022, doi:10.1111/maps.12310.

Jaret, S.J., Woerner, W.R., Phillips, B.L., Ehm, L., Nekvasil, H., Wright, S.P., and Glotch, T.D., 2015, Maskelynite formation via solid-state transformation: Evidence of infrared and X-ray anisotropy: Journal of Geophysical Research : Planets, v. 120, p. 570-587.

Jaret, S.J., Johnson, J.R., Sims, M., DiFrancesco, N., and Glotch, T.D., 2018, Microspectroscopic and petrographic comparison of experimentally shocked albite, andesine, and bytownite: Journal of Geophysical Research: Planets, v. 123, p. 1701-1722, doi:10.1029/2018JE005523.

Jessberger, E., and Ostertag, R., 1982, Shock-effects on the K-Ar system of plagioclase feldspar and the age of anorthosite inclusions from North-Eastern Minnesota: Geochimica et Cosmocimica Acta, v. 46, p. 1465 - 1471.

Johnson, J.R., 2003, Visible/near-infrared spectra of experimentally shocked plagioclase feldspars: Journal of Geophysical Research, v. 108, p. 5120, doi:10.1029/2003JE002127.

Johnson, J.R., Hörz, F., Lucey, P.G., and Christensen, P.R., 2002a, Thermal infrared spectroscopy of experimentally shocked anorthosite and pyroxenite; implications for remote sensing of Mars: Journal of Geophysical Research, v. 107, p. 14, doi:http://dx.doi.org/10.1029/2001JE001517.

Johnson, J.R., Staid, M.I., and Titus, T.N., 2002b, Shocked plagioclase signatures in thermal emission spectrometer data of Mars: Abstracts of Papers Submitted to the Lunar and Planetary Science Conference, v. 33, p. 0-Abstract 1345.

Johnson, J.R., Hörz, F., and Staid, M.I., 2003, Thermal infrared spectroscopy and modeling of experimentally shocked plagioclase feldspars: American Mineralogist, v. 88, p. 15751582.

Kaus, A., and Bischoff, A., 2000, Cathodoluminescence (CL) properties of shocked plagioclase: Meteoritics \& Planetary Science, v. 35, p. A86. 
1096

1097

1098

1099

1100

1101

1102

1103

1104

1105

1106

1107

1108

1109

1110

1111

1112

1113

1114

1115

1116

1117

1118

1119

1120

1121

1122

1123

1124

1125

1126

1127

1128

1129

1130

1131

Kayama, M., Gucsik, A., Nishido, H., Ninagawa, K., Tsuchiyama, A., and Goetze, J., 2009a, Cathodoluminescence and Raman spectroscopic characterization of experimentally shocked plagioclase: LPI Contribution, p. 49.

Kayama, M., Nakazato, T., Nishido, H., Ninagawa, K., Gucsik, A., and Goetze, J., 2009b, Cathodoluminescence characterization of maskelynite and alkali feldspar in shergottite: LPI Contribution, p. 50.

Kayama, M., Nishido, H., Ninagawa, K., Gucsik, A., and Goetze, J., 2009c, Cathodoluminescence of shocked plagioclase and alkali feldspar from Ries Crater, Germany: LPI Contribution, p. 51.

Kayama, M., Nishido, H., Sekine, T., Nakazato, T., Gucsik, A., and Ninagawa, K., 2012, Shock barometer using cathodoluminescence of alkali feldspar: Journal of Geophysical Research, v. 117, p. E09004.

Kayama, M., Sekine, T., Tomioka, N., Nishido, H., Kato, Y., Ninagawa, K., Kobayashi, T., and Yamaguchi, A., 2018, Cathodoluminescence of high-pressure feldspar minerals as a shock barometer: Meteoritics and Planetary Science, v. 53, p. 1476-1488, doi:10.1111/maps.13092.

Kieffer, S.W., 1971, Shock metamorphism of the Coconino sandstone at Meteor Crater, Arizona: Journal of Geophysical Research, v. 76, p. 5449-5473.

Kieffer, S.W., Schaal, R.B., Gibbons, R., Horz, R., Milton, D.J., and Dube, A., 1976, Shocked basalt from Lonar impact Crater, India, and experimental analogues: Lunar and Planetary Science Conference Proceedings, v. 1, p. 1391-1412.

Kleeman, J.D., 1971, Formation of diaplectic glass by experimental shock loading of orthoclase: Journal of Geophysical Research, v. 76, p. 5499-5503, doi:10.1029/JB076i023p05499.

Klein, C., and Philpotts, A., 2016, Introduction to mineralogy and petrology: Cambridge, Cambridge University Press.

Knight, K.S., Price G.D., 2008, Powder Neutron-diffraction studies of clinopyroxenes. I. The crystal structure and thermoelastic properties of jadeite between 1.5 and $270 \mathrm{~K}$ : The Canadian Mineralogist, v. 46, p. 1593-1622.

Koeberl, C., Reimold, W.U., Kracher, A., Träxler, B., Vormaier, A., and Körner, W., 1996, Mineralogical, petrological, and geochemical studies of drill core samples from the Manson impact structure, Iowa, in Koeberl, C. and Anderson, R.R. eds., The Manson impact structure, Iowa; anatomy of an impact crater, Geological Society of America, v. 302, p. 0, doi:10.1130/0-8137-2302-7.145.

Kubo, T., Kimura, M., Kato, T., Nishi, M., Tominaga, A., Kikegawa, T., and Funakoshi, K., 2010, Plagioclase breakdown as an indicator for shock conditions of meteorites: Nature Geoscience, v. 3, p. 41-45, doi:10.1038/NGEO704. 
1132 Kubo, T., Kono, M., Imamura, M., Kato, T., Uehara, S., Kondo, T., Higo, Y., Tange, Y., and

1133

1134

1135

1136

1137

1138

1139

1140

1141

1142

1143

1144

1145

1146

1147

1148

1149

1150

1151

1152

1153

1154

1155

1156

1157

1158

1159

1160

1161

1162

1163

1164

1165

1166

1167 Kikegawa, T., 2017, Formation of a metastable hollandite phase from amorphous plagioclase: A possible origin of lingunite in shocked chondritic meteorites: Physics of the Earth and Planetary Interiors, v. 272, p. 50-57, doi:10.1016/j.pepi.2017.09.006.

Lambert, P., 1979, Fractures induced by shock in quartz and feldspar: Mineralogical Magazine, v. 43, p. 527-533, doi:10.1180/minmag.1979.043.328.13.

Langenhorst, F., 2002, Shock metamorphism of some minerals: Basic introduction and microstructural observations: Bulletin of the Czech Geological Survey, v. 77, p. 265-282.

Langenhorst, F., and Deutsch, A., 1994, Shock experiments on pre-heated $\alpha$ - and $\beta$-quartz: I. Optical and density data: Earth and Planetary Science Letters, v. 125, p. 407-420, doi:10.1016/0012-821X(94)90229-1.

Langenhorst, F., and Deutsch, A., 2012, Shock metamorphism of minerals: Elements, v. 8, p. 31-36, doi:10.2113/gselements.8.1.31.

Langenhorst, F., and Dressler, B., 2003, First observation of silicate hollandite in a terrestrial rock: LPI Contribution, v. 1167, p. 0-Abstract 4046.

Langenhorst, F., and Poirier, J.-P., 2000, Anatomy of black veins in Zagami; clues to the formation of high-pressure phases: Earth and Planetary Science Letters, v. 184, p. 37-55, doi:http://dx.doi.org/10.1016/S0012-821X(00)00317-4.

Langenhorst, F., Deutsch, A., Stöffler, D., and Hornemann, U., 1992, Effect of temperature on shock metamorphism of single-crystal quartz: Nature, v. 356, p. 507-509, doi:10.1038/356507a0.

Langenhorst, F., Joreau, P., and Doukhan, J.C., 1995, Thermal and shock metamorphism of the Tenham chondrite: A TEM examination: Geochimica et Cosmochimica Acta, v. 59, p. 1835-1845, doi:10.1016/0016-7037(95)00086-F.

Lee, M.R., Parsons, I., Edwards, P.R., and Martin, R.W., 2007, Identification of cathodoluminescence activators in zoned alkali feldspars by hyperspectral imaging and electron-probe microanalysis: American Mineralogist, v. 92, p. 243-253, doi:10.2138/am.2007.2160.

Leichmann, J., Broska, I., and Zachovalová, K., 2003, Low-grade metamorphic alteration of feldspar minerals: A CL study: Terra Nova, v. 15, p. 104-108, doi:10.1046/j.13653121.2003.00467.x.

Letoullec, R., Pinceaux, J.P., and Loubeyre, P., 1988, The membrane diamond anvil cell: A new device for generating continuous pressure and temperature variations: high pressure research, v. 1, p. 77-90, doi:10.1080/08957958808202482.

Liu, L.-G., 1978, High-pressure phase transformations of albite, jadeite and nepheline: Earth and Planetary Science Letters, v. 37, p. 438-444, doi:10.1016/0012-821X(78)90059-6. 
Liu, X., 2006, Phase relations in the system $\mathrm{KAlSi}_{3} \mathrm{O}_{8}-\mathrm{NaAlSi}_{3} \mathrm{O}_{8}$ at high pressure-high temperature conditions and their implication for the petrogenesis of lingunite: Earth and Planetary Science Letters, v. 246, p. 317-325.

Liu, L.-G., and El Gorsey, A., 2007, High-pressure phase transitions of the feldspars, and further characterization of lingunite: International Geology Review, v. 49, p. 854-860, doi:10.2747/0020-6814.49.9.854.

Lyon, R.J.P., 1963, Evaluation of infrared spectrophotometry for compositional analysis of lunar and planetary soils: NASA Technical Note D-1871.

Ma, C., Tschauner, O., Beckett, J.R., Liu, Y., Rossman, G.R., Zhuravlev, K., Prakapenka, V., Dera, P., and Taylor, L.A., 2015, Tissintite, $(\mathrm{Ca}, \mathrm{Na}, \oplus) \mathrm{AlSi}_{2} \mathrm{O}_{6}$, a highly-defective, shockinduced, high-pressure clinopyroxene in the Tissint martian meteorite: Earth and Planetary Science Letters, v. 422, p. 194-205, doi:10.1016/j.eps1.2015.03.057.

Ma, C., Tschauner, O. and Beckett, J.R., 2017, A new high-pressure calcium aluminosilicate $\left(\mathrm{CaAl}_{2} \mathrm{Si}_{3.5} \mathrm{O}_{11}\right)$ in martian meteorites: another after-life for plagioclase and connections to the CAS phase: Lunar and Planetary Science XLVIII, 1128.

Ma C., Tschauner, O., Beckett, J.R., Rossman G. R., Prescher C., Prakapenka, V.B. Bechtel, H. A., and MacDowell, A., 2018, Liebermannite, $\mathrm{KAlSi}_{3} \mathrm{O}_{8}$, a new shock-metamorphic, highpressure mineral from the Zagami Martian meteorite: Meteoritics and Planetary Science, v. 53, p. 50-61.

Marsh, S. P. (Ed.), 1980, LASL shock Hugoniot data: University of California Press, Berkeley.

Melosh, H.J., 1989, Impact cratering: A geologic process: New York, Oxford University Press, $245 \mathrm{p}$.

Milton, D.J., and de Carli, P.S., 1963, Maskelynite: formation by explosive shock: Science, v. 140, p. 670 LP - 671, doi:10.1126/science.140.3567.670.

Moreau, J., Kohout, T., and Wünnemann, K., 2017, Shock-darkening in ordinary chondrites: Determination of the pressure-temperature conditions by shock physics mesoscale modeling: Meteoritics and Planetary Science, v. 52, p. 2375-2390, doi:10.1111/maps.12935.

Müller, W.F., and Hornemann, U., 1969, Shock-induced planar deformation structures in experimentally shock-loaded olivines and in olivines from chondritic meteorites: Earth and Planetary Science Letters, v. 7, p. 251-264, doi:10.1016/0012-821X(69)90062-4.

Myers, S.A., Cygan, R.T., Assink, R.A., and Boslough, M.B., 1998, ${ }^{29}$ Si MAS NMR relaxation study of shocked Coconino Sandstone from Meteor Crater, Arizona: Physics and Chemistry of Minerals, v. 25, p. 313-317, doi:10.1007/s002690050120.

Nagy, S., Gucsik, A., Bérczi, S., Ninagawa, K., Nishido, H., Kereszturi, A., Hargitai, H., and Okumura, T., 2008, K-feldspar and biotite as shock indicator minerals from Bosumtwi 
impact crater: Abstracts of Papers Submitted to the Lunar and Planetary Science Conference, v. 39, Abstract 1144.

Nelson, S.T., and Montana, A., 1992, Sieve-textured plagioclase in volcanic rocks produced by rapid decompression: American Mineralogist, v. 77, p. 1242-1249.

Ogilvie, P., Gibson, R.L., Reimold, W.U., Deutsch, A., and Hornemann, U., 2011, Experimental investigation of shock metamorphic effects in a metapelitic granulite: The importance of shock impedance contrast between components: Meteoritics and Planetary Science, v. 46, p. 1565-1586, doi:10.1111/j.1945-5100.2011.01250.x.

Ohtani, E., Kimura, Y., Kimura, M., Takata, T., Kondo, T., and Kubo, T., 2004, Formation of high-pressure minerals in shocked L6 chondrite Yamato 791384: constraints on shock conditions and parent body size: Earth and Planetary Science Letters, v. 227, p. 505-515, doi:10.1016/j.eps1.2004.08.018.

Okuno, M., 2003, Structural evolution of quartz and feldspar crystals and their glasses by shock compression, in Davison, L., Horie, Y., and Sekine, T. eds., High-pressure shock compression of solids V. Shock wave and high pressure phenomena, New York.

Ostertag, R., 1982, Annealing behaviour of diaplectic plagioclase glass, in Lunar and Planetary Science Conference, p. 607-608.

Ostertag, R., 1983, Shock experiments on feldspar crystals: Journal of Geophysical Research, v. 88, Suppl., p. B364-B376, doi:10.1029/JB088iS01p0B364.

Papike, J.J., Taylor, L., and S., S., 1991, Lunar minerals, in Heiken, G.H., Vaniman, D., and French, B.M. eds., Lunar sourcebook: A user's guide to the Moon, Cambridge, Cambridge University Press, p. 736.

Parsons, I., and Lee, M.R., 2009, Mutual replacement reactions in alkali feldspars I: Microtextures and mechanisms: Contributions to Mineralogy and Petrology, v. 157, p. 641-661, doi:10.1007/s00410-008-0355-4.

Parsons, I., Steele, D.A., Lee, M.R., and Magee, C.W., 2008, Titanium as a cathodoluminescence activator in alkali feldspars: American Mineralogist, v. 93, p. 875-879, doi:10.2138/am.2008.2711.

Parsons, I., Gerald, J.D.F., and Lee, M.R., 2015, Routine characterization and interpretation of complex alkali feldspar intergrowths: American Mineralogist, v. 100, p. 1277-1303, doi:10.2138/am-2015-5094.

Pati, J.K., Jourdan, F., Armstrong, R.A., Reimold, W.U., and Prakash, K., 2010, First SHRIMP $\mathrm{U}-\mathrm{Pb}$ and ${ }^{40} \mathrm{Ar} /{ }^{39} \mathrm{Ar}$ chronological results from impact melt breccia from the Paleoproterozoic Dhala impact structure, India, in Gibson, R.L. and Reimold, W.U. eds., Large Meteorite Impacts and Planetary Evolution IV, Geological Society of America, v. 465, doi:10.1130/2010.2465(27). 
Pickersgill, A.E., and Lee, M.R., 2015, Identifying planar deformation features using EBSD and FIB, in Bridging the Gap III: Impact Cratering In Nature, Experiments, and Modeling, p. 1056.

Pickersgill, A.E., Flemming, R.L., and Osinski, G.R., 2015a, Toward quantification of strainrelated mosaicity in shocked lunar and terrestrial plagioclase by in situ micro-X-ray diffraction: Meteoritics and Planetary Science, v. 50, p. 1851-1862, doi:10.1111/maps.12514.

Pickersgill, A.E., Osinski, G.R., and Flemming, R.L., 2015b, Shock effects in plagioclase feldspar from the Mistastin Lake impact structure, Canada: Meteoritics and Planetary Science, v. 50, p. 1546-1561, doi:10.1111/maps.12495.

Pickersgill, A.E., Lee, M.R., Daly, L., Mark, D.F., and IODP-ICDP Expedition 364 Science Party, 2017, Planar microstructures (lamellar subgrains) in feldspar from the Chicxulub impact structure, in 80th Annual Meeting of the Meteoritical Society, p. 6182.

Pittarello, L., and Koeberl, C., 2017, Shock-induced planar features in plagioclase: a project on measurements and investigations on their occurrence in relation with the An content, in 80th Annual Meeting of the Meteoritical Society.

Pittarello, L., Schulz, T., Koeberl, C., Hoffmann, J.E., and Münker, C., 2013, Petrography, geochemistry, and Hf-Nd isotope evolution of drill core samples and target rocks from the El'gygytgyn impact crater, NE Chukotka, Arctic Russia: Meteoritics and Planetary Science, v. 48, p. 1160-1198, doi:10.1111/maps.12088.

Pittarello, L., Roszjar, J., Mader, D., Debaille, V., Claeys, P., and Koeberl, C., 2015, Cathodoluminescence as a tool to discriminate impact melt, shocked and unshocked volcanics: A case study of samples from the El'gygytgyn impact structure: Meteoritics and Planetary Science, v. 50, p. 1954-1969, doi:10.1111/maps.12559.

Pittarello, L., Daly, L., Pickersgill, A.E., Ferrière, L., and Lee, M.R., 2020a, Shock metamorphism in plagioclase and selective amorphization: Meteoritics \& Planetary Science, v. 55, p. 1103-1115, doi:10.1111/maps.13494

Pittarello, L., Fritz, J., Roszjar, J., Lenz, C., Chanmuang, C.N., and Koeberl, C., 2020b, Partial amorphization of experimentally shocked plagioclase: A spectroscopic study: Meteoritics and Planetary Science, v. 55, p. 669-678, doi:10.1111/maps.13445.

Pittarello, L., Ferrière, L., Feignon, J.-G., Osinski, G. R., and Koeberl, C., 2020c, Preferred orientation distribution of shock-induced planar microstructures in quartz and feldspar: Meteoritics \& Planetary Science, v. 55, p. 1082-1092, doi: 10.1111/MAPS.13490-3304

Poelchau, M.H., and Kenkmann, T., 2011, Feather features; a low-shock-pressure indicator in quartz: Journal of Geophysical Research, v. 116, p. B02201, doi:http://dx.doi.org/10.1029/2010JB007803. 
Poldervaart, A., and Gilkey, A.K., 1954, On clouded plagioclase: American Mineralogist, v. 35, p. 75-91.

Prior, D.J. et al., 1999, The application of electron backscatter diffraction and orientation contrast imaging in the SEM to textural problems in rocks: American Mineralogist, v. 84, p. 1741-1759, doi:10.2138/am-1999-11-1204.

Putnis, A., Hinrichs, R., Putnis, C. V., Golla-Schindler, U., and Collins, L.G., 2007, Hematite in porous red-clouded feldspars: Evidence of large-scale crustal fluid-rock interaction: Lithos, v. 95, p. 10-18, doi:10.1016/j.lithos.2006.07.004.

Reeder, R.J., and Michel, F.M., 2013, Application of total X-ray scattering methods and pair distribution function analysis for study of structure of biominerals, in Methods in Enzymology, doi:10.1016/B978-0-12-416617-2.00020-5.

Reimold, W.U., and Miller, R.M., 1989, The Roter Kamm impact crater, SWA/Namibia: Lunar and Planetary Science Conference Proceedings, v. 19, p. 711-732.

Reinhard, M., 1931, Universal Drehtischmethoden : Einführung in die kristalloptischen Grundbegriffe und die Plagioklasbestimmung: Basel, Verlag, von B. Wepf \& Cie., 119 p.

Reynard, B., Okuno, M., Shimada, Y., Syono, Y., and Willaime, C., 1999, A Raman spectroscopic study of shock-wave densification of anorthite $\left(\mathrm{CaAl}_{2} \mathrm{Si}_{2} \mathrm{O}_{8}\right)$ glass: Physics and Chemistry of Minerals, v. 26, p. 432-436.

Ringwood, A.E., Reid, A.F., and Wadsley, A.D., 1967, High pressure transformation of alkali aluminosilicates and aluminogermanates: Earth and Planetary Science Letters, v. 3, p. 3840, doi:http://dx.doi.org/10.1016/0012-821X(67)90008-8.

Robertson, P.B., 1973, Shock metamorphism of potassic feldspars: Durham University, 326 p.

Robertson, P.B., 1975, Experimental shock metamorphism of maximum microcline: Journal of Geophysical Research (1896-1977), v. 80, p. 1903-1910, doi:10.1029/JB080i014p01903.

Robertson, P.B., Dence, M.R., and Vos, M.A., 1968, Deformation in rock-forming minerals from Canadian craters, in French, B.M. and Short, N.M. eds., Shock metamorphism of natural materials, Baltimore, MD, Mono Book Corp., p. 433-452.

Roddy, D.J., Pepin, R.O., and Merrill, R.B. (Eds.), 1978, Impact and explosion cratering: Toronto, Pergamon Press, 1301 p.

Rubin, A.E., 1992, A shock-metamorphic model for silicate darkening and compositionally variable plagioclase in $\mathrm{CK}$ and ordinary chondrites: Geochimica et Cosmochimica Acta, v. 56, p. 1705-1714, doi:10.1016/0016-7037(92)90236-C.

Rucks, M.J., Whitaker, M.L., Glotch, T.D., Parise, J.B., Jaret, S.J., Catalano, T., and Dyar, M.D., 2018, Making tissintite: Mimicking meteorites in the multi-anvil: American Mineralogist, v. 103, p. 1516-1519, doi:10.2138/am-2018-6539. 
1311 Seifert, K.E., 1964, The genesis of plagioclase twinning in the Nonewaug Granite: The American 1312 Mineralogist, v. 49, p. 297-320.

1313 Sharp, T.G., and DeCarli, P., 2006, Shock effects in meteorites, in Meteorites and the early solar 1314 system II, p. 653-677.

1315 Sharp, T.G., Walton, E.L., Hu, J., Agee, C., 2019, Shock conditions recorded in NWA 8159

1316

1317 martian augite basalt with implications for the impact cratering history on Mars:

1318

1319

1320

1321

1322

1323

1324

1325

1326

1327

1328 Geochimica et Cosmochimica Acta, v. 246, p. 197-212.

Short, N.M., and Gold, D.P., 1996, Petrography of shocked rocks from the central peak at the Manson impact structure, in Koeberl, C. and Anderson, R.R. eds., Special Paper Geological Society of America, Geological Society of America (GSA), Boulder, CO, v. 302, p. 245-265.

Sims, M. et al., 2019, Pressure-induced amorphization in plagioclase feldspars: A time-resolved powder diffraction study during rapid compression: Earth and Planetary Science Letters, v. 507, p. 166-174, doi:10.1016/j.eps1.2018.11.038.

Sims, M., Jaret, S.J., Johnson, J.R., Whitaker, M.L., and Glotch, T.D., 2020, Unconventional high-pressure Raman spectroscopy study of kinetic and peak pressure effects in plagioclase feldspars: Physics and Chemistry of Minerals, v. 47, p. 1-10, doi:10.1007/s00269-02001080-z.

1329 Smith, J. V, and Brown, W.L., 1988, Feldspar minerals: Berlin, Springer-Verlag, 828 p.

1330 Spry, A.H., 1969, Metamorphic textures: Oxford, New York, Pergamon Press, 350

1331 Stähle, V., Altherr, R., Nasdala, L., and Ludwig, T., 2011, Ca-rich majorite derived from high-

1332

1333

1334 temperature melt and thermally stressed hornblende in shock veins of crustal rocks from the Ries impact crater (Germany): Contributions to Mineralogy and Petrology, v. 161, p. 275-291, doi:10.1007/s00410-010-0531-1.

1335

Stebbins, J.F., and Xue, X., 2014, NMR spectroscopy of inorganic Earth materials: Reviews in 1336 mineralogy and geochemistry, v. 78, p. 605-653, doi:10.2138/rmg.2014.78.15.

1337

Stöffler D., 1966, Zones of Impact Metamorphism in the Crystalline Rocks of the Nördlinger Ries Crater: Contributions to Mineralogy and Petrology, v. 12, p. 15-24.

1339

1340

1341

Stöffler, D., 1967, Deformation und Umwandlung von Plagioklas durch Stoßwellen in den Gesteinen des Nördlinger Ries: Contributions to Mineralogy and Petrology, v. 16, p. $51-$ 83, doi:10.1007/BF00371608.

Stöffler, D., 1971, Progressive metamorphism and classification of shocked and brecciated crystalline rocks at impact craters: Journal of Geophysical Research, v. 76, p. 5541-5551.

1344 Stöffler, D., 1972, Deformation and transformation of rock-forming minerals by natural and 1345 1346 experimental shock processes: I. Behavior of minerals under shock compression: Fortschritte der Mineralogie, v. 49, p. 50-113. 
Stöffler, D., 1974, Deformation and transformation of rock-forming minerals by natural and experimental shock processes: II. Physical properties of shocked minerals: Fortschritte der Mineralogie, v. 51, p. 256-289.

Stöffler, D., and Grieve, R.A.F., 2007, Impactites, in Fettes, D. and Desmons, J. eds., Metamorphic Rocks: A classification and glossary of terms, Recommendations of the International Union of Geological Sciences, Cambridge, UK, Cambridge University Press, p. 82-92, and 111-242.

Stöffler, D., and Hornemann, U., 1972, Quartz and feldspar glasses produced by natural and experimental shock: Meteoritics, v. 7, p. 371-394.

Stöffler, D., and Langenhorst, F., 1994, Shock metamorphism of quartz in nature and experiment: I. Basic observation and theory: Meteoritics, v. 29, p. 155-181.

Stöffler, D., Schulien, S., and Ostertag, R., 1975, Rock 61016: multiphase shock and crystallization history of a polymict troctolitic-anorthositic breccia: Lunar and Planetary Science Conference Proceedings, v. 1, p. 673-692.

Stöffler, D., Ostertag, R., Jammes, C., Pfannschmidt, G., Sen Gupta, P. R., Simon, S. B., Papike, J. J., and Beauchamp, R. H., 1986, Shock metamorphism and petrography of the Shergotty achondrite: Geochimica et Cosmochimica Acta v. 50, p. 889-903.

Stöffler, D., Keil, K., and Scott, E.R.D., 1991, Shock metamorphism of ordinary chondrites: Geochimica et Cosmochimica Acta, v. 55, p. 3845-3867, doi:http://dx.doi.org/10.1016/0016-7037(91)90078-J.

Stöffler, D., Hamann, C., and Metzler, K., 2018, Shock metamorphism of planetary silicate rocks and sediments: Proposal for an updated classification system: Meteoritics and Planetary Science, v. 53, p. 5-49, doi:10.1111/maps.12912.

Stöffler, D., Hamann, C., and Metzler, K., 2019, Addendum to "Stöffler, D., Hamann, C., and Metzler, K., Shock metamorphism of planetary silicate rocks and sediments: Proposal for an updated classification system. Meteoritics \& Planetary Science 53, 5-49. Meteoritics \& Planetary Science 54, 946-949. Stöffler, D., and Hornemann, U., 1972, Quartz and feldspar glasses produced by natural and experimental shock: Meteoritics, v. 7, p. 371-394.

Taylor, F.C., and Dence, M.R., 1969, A probable meteorite origin for Mistastin Lake, Labrador: Canadian Journal of Earth Sciences, v. 6, p. 39-45.

Thiel, M. van (Ed.), 1977, Compendium of shock wave data, (Livermore: Lawrence Livermore Laboratory Report UCRL-50108, 1977), p. 710-712.

Tomioka, N., and Miyahara, M., 2017, High-pressure minerals in shocked meteorites: Meteoritics and Planetary Science, v. 52, p. 2017-2039.

Tomioka, N., Mori, H., and Fujino, K., 2000, Shock-induced transition of NaAISi308 feldspar into a hollandite structure in a L6 chondrite: Geophysical Research Letters, v. 27, p. 39974000 . 
1384 Tomioka et al., 2007, Static amorphization of plagioclase: Comparison to the formation pressure of diaplectic glass in shock experiments: Meteoritics and Planetarey Science, v. 42, p. A148

Tomioka, N., Kondo, H., Kunikata, A., and Nagai, T., 2010, Pressure-induced amorphization of albitic plagioclase in an externally heated diamond anvil cell: Geophysical Research Letters, v. 37, p. 1-5, doi:10.1029/2010GL044221.

Treiman, A., and Treado, P., 1998, Martian maskelynite? Raman spectra of plagioclasecomposition glasses from ALH84001, EETA 79001, and ALHA 77005, in 29th Lunar and Planetary Science Conference, p. Abstract 1196.

Trepmann, C., Whitehead, J., and Spray, J., 2003, Shock effects in target rocks from the Charlevoix impact structure, Quebec, Canada: Abstracts of Geological Society of America Northeastern Section - 38th Annual Meeting, p. 7- 17.

Tschermak, G., 1883, Beitrag zur Klassifikation der Meteoriten: Sitzungsberichte der Mathematisch-Naturwissenschaftlichen Klasse der Kaiserlichen Akademie der Wissenschaften, Wien, v. 88, p. 347-371.

Tschermak, G., 1872, Die Meteoriten von Shergotty und Gopalpur: Sitzungsberichte der Mathematisch-Naturwissenschaftlichen Klasse der Kaiserlichen Akademie der Wissenschaften, Wien, v. 65, p. 122-145.

Turner, F.J., 1947, Determination of plagioclase with the four-axis universal stage: American Mineralogist, v. 32, p. 389-410.

Vernon, R.H., 1975, Deformation and recrystallization of a plagioclase grain: American Mineralogist, v. 60, p. 884-888.

Vinet, N., Flemming, R.L., and Higgins, M.D., 2011, Crystal structure, mosaicity, and strain analysis of Hawaiian olivines using in situ X-ray diffraction: American Mineralogist, v. 96, p. 486-497.

1414 Walton, E.L., Sharp, T.G., Hu, J., and Filiberto, J., 2014 Heterogeneous mineral assemblages in martian meteorite Tissint as a result of a recent small impact event on Mars. Geochimica et Cosmochimica Acta. 140: 334-348

1417 Walton, E.L., Sharp, T.G., Hu, J., 2016, Frictional melting processes and the generation of shock veins in terrestrial impact structures: Evidence from the Steen River impact structure, Alberta, Canada: Geochimica et Cosmochimica Acta, v. 180, p. 256-270. 
White, J.C., 1993, Shock-induced amorphous textures in plagioclase, Manicouagan, Quebec, Canada: Contributions to Mineralogy and Petrology, v. 113, p. 524-532.

1422 Whitehead, J., Grieve, R.A.F., and Spray, J.G., 2002, Mineralogy and petrology of melt rocks from the Popigai impact structure, Siberia: Meteoritics and Planetary Science, v. 37, p. 623-647, doi:10.1111/j.1945-5100.2002.tb00844.x.

Whitney, P.R., 1972, Spinel inclusions in plagioclase of metagabbros from the Adirondack Highlands: American Mineralogist, v. 57, p. 1429-1436.

Williams, Q., and Jeanloz, R., 1988, Spectroscopic evidence for pressure-induced coordination changes in silicate glasses and melts: Science, v. 239, p. 902 LP - 905, doi:10.1126/science.239.4842.902.

Wittmann, A., Korotev, R.L., Jolliff, B.L., Nishizumi, K., Jull, A.J.T., Caffee, M.W., Zanetti, M., Irving, A.J., 2019, Petrogenesis of lunar impact melt rock meteorite Oued Awlitis 001: Meteoritics and Planetary Science, v. 54, p. 2167-2188.

Xu, C., Zhao, S.R., Li, C., and He, X., 2016, Plagioclase twins in a basalt: An electron backscatter diffraction study: Journal of Applied Crystallography, v. 49, p. 2145-2154, doi:10.1107/S1600576716015739.

Yagi, A., Suzuki, T., and Akaogi, M., 1994, High pressure transitions in the system KAlSi3O8NaAlSi3O8: Physics and Chemistry of Minerals, v. 21, p. 12-17.

Zoltai, T., and Stout, J.H., 1984, Mineralogy: concepts and principles: Minneapolis, Burgess Publishing Company, $505 \mathrm{p}$.

\section{FIGURE CAPTIONS}

Figure 1: Plot showing the relationship between anorthite content and pressure needed to

1443 form partly to fully isotropic plagioclase. The overall trend demonstrates that plagioclase of

1444 higher mole \% An content results in complete amorphization at lower pressures than plagioclase

1445 of lower mole \% An content. The graph is based on shock recovery experimental data

1446 summarized by Fritz et al. (2019a).

Figure 2: Shock pressure versus specific volume Hugoniot plot of a representative

1449 plagioclase $\left(\mathrm{An}_{\sim 50}\right)$ illustrating the three distinct phase regimes (I, low pressure; II, mixed; and 
1450 III, high pressure) and the range of the Hugoniot elastic limit (HEL). Data from Marsh (1980)

1451 and van Thiel (1977).

1452

Figure 3: A) Transmitted light photomicrograph of heavily fractured anorthite in Apollo

1454 sample 15415,90; fractures are highlighted by offset twins when viewed between crossed

1455 polarizers. B) Backscattered electron image of fractured plagioclase (albite, dark grey) from the

1456 El'gygytgyn impact structure, with planar features (black arrows) in the lower right corner.

Figure 4: Undulatory extinction in Apollo samples 76335,55 (A) and 60215,13 (B)

1459 between cross-polarized light, as the stage is rotated a wave of extinction passes through the 1460 crystal.

Figure 5: Planar microstructures in oligoclase from the Tenoumer impact structure (A,

1463 B); note the planar features in (B) only exist in alternating twins; after Jaret et al. (2014). C)

1464 Andesine $\left(\mathrm{An}_{23}\right)$ from the Manicouagan impact structure showing multiple sets of planar

1465 features. D) K-rich feldspar with albite exsolution (beige, labeled Ab) and tartan twins spread

1466 over the whole grain from the Gardnos impact structure; planar features on the right side of the

1467 image (parallel to white lines) with the same orientation as polysynthetic twins.

Figure 6: Plane-polarised photomicrographs of andesine experimentally shocked to 25

$1470 \mathrm{GPa}(\mathrm{A})$ and $56 \mathrm{GPa}(\mathrm{B})$ showing progressive degrees of shock-darkening. Electron probe

1471 microanalysis, Raman, and FTIR analyses suggest this darkening is purely optical, and does not

1472 correspond with observable chemical or structural changes. After Jaret et al. (2018). 
1475 martian meteorite, highlighting preserved external crystal morphology and irregular fractures 1476 extending from maskelynite grain margins into surrounding igneous pyroxene (after Tschermak

1477 1872, drawn at 75x magnification, estimated grain size is $\sim 400 \mu \mathrm{m})$. B) Composite reflected light

1478 (left) and transmitted light between crossed polarizers (right) image showing a partly isotropic

1479 plagioclase crystal enclosed by olivine in martian meteorite Chassigny, though the plagioclase is

1480 only partly isotropic, the same fracture pattern is observed as in the illustration by Tschermak

1481 (A). C,D) Partially isotropic plagioclase in PPL (C) and XPL (D) from Apollo 15 sample

148215684,4 . Black areas in XPL remain extinct on rotation of the stage. E,F) Completely isotropic

1483 plagioclase in basalt from Lonar crater, India (after Jaret et al. 2015). G) Plane-polarised

1484 transmitted light image of maskelynite from the Shergotty meteorite $(\sim 30 \mathrm{GPa})$ which includes a

1485 perfectly preserved magmatic pyroxene. H) Plane-polarised transmitted light image of

1486 maskelynite from the Los Angeles Martian meteorite ( $45 \mathrm{GPa})$ with a pyroxene fragment

1487 partially affected by eutectic melting.

Figure 8: Plots demonstrating the relationship between refractive index, pressure, and

1490 composition of diaplectic feldspar glasses. A) Refractive index vs. An content. Displayed are

1491 isobars indicating the shock pressures that result in a plagioclase normative phase with a given

1492 index of refraction. Fields indicating the optical properties, birefringent or isotropic, are

1493 indicated by grey lines; after Fritz et al. (2005b) using data from Stöffler et al. (1986). B)

1494 Refractive indices of diaplectic feldspar glasses from experiments in the pressure range from 28$149545 \mathrm{GPa}$. After Ostertag (1983). 
Figure 9: IR spectra of 2 orientations from (A) crystalline, (B) diaplectic glass, and (C)

1498 melt glass of labradorite composition. Crystalline labradorite exhibits multiple peaks, all

1499 showing shifts with orientation indicating the anisotropic nature of the material. Both melt glass

1500 and diaplectic glass are amorphous (one broad peak) but diaplectic glass retains orientation

1501 effects not observed in the melt glass sample. After Jaret et al. (2015).

1502

Figure 10: Plane-polarised light photomicrograph of plagioclase glass displaying bubbles

1504 and flow textures surrounded by brown stained olivine, in some areas the plagioclase glass has

1505 developed a rim of recrystallized plagioclase. From the strongly shocked ALH (Allan Hills)

150677005 martian meteorite.

Figure 11: Photomicrographs of sieve or checkerboard feldspar. A, B) Plagioclase from

1509 Gow Lake impact structure, showing preserved polysynthetic twins between crossed polarizers

1510 (B). C) Plane-polarized light photomicrographs showing magnified view of checkerboard

1511 feldspar in a clast from Gow Lake impact melt rock; D) sieve-textured feldspar from a volcanic 1512 andesite (image credit: Dr Alessandro Mommio).

Figure 12: Cathodoluminescence images and spectra of plagioclase $\left(\mathrm{An}_{55}\right)$ experimentally

1515 shocked to $28 \mathrm{GPa}$ by Fritz et al., (2019a). A) Transmitted light photomicrograph between

1516 crossed polarizers (XPL) showing heterogeneous distribution of isotropic domains (black). B)

1517 Optical microscope cathodoluminescence (OM-CL) image of the same grain as in (A), showing 1518 three spectra locations (1-3). Areas of higher crystallinity (point 1) have higher luminescence 
1519 than isotropic domains (points 2 and 3). C) CL spectra corresponding to points 1-3 in (B), further

1520 showing that the domains with remaining crystallinity have higher luminescence than those that

1521 are isotropic, after Pittarello et al. (2020b).

Figure 13: Raman spectra of shocked feldspar. A) Raman spectra of andesine ( $\left.\mathrm{An}_{43}\right)$ :

1524 unshocked (0 GPa), shocked (up to $29 \mathrm{GPa}$ ), and diaplectic glass (>29 GPa). For clarity, three

1525 spectra of $0 \mathrm{GPa}$ (top line), $26 \mathrm{GPa}$ (middle line), and $56 \mathrm{GPa}$ (bottom line), representing the

1526 aforementioned categories (unshocked, shocked, diaplectic glass) are shown here. Up to

1527 pressures of $29 \mathrm{GPa}$ (middle line), increasing shock corresponds to an overall decrease in peak

1528 intensity and causes the $480 / 510 \Delta \mathrm{cm}^{-1}$ peak ratio to approach 1 . Above $29 \mathrm{GPa}$ (bottom line),

1529 the sample appears amorphous, and exhibits a different Raman pattern, with two broad peaks at

$1530 \sim 500 \Delta \mathrm{cm}^{-1}$ and $580 \Delta \mathrm{cm}^{-1}$. Data from Jaret et al. (2018). B) Raman spectra of diaplectic

1531 feldspar glass with three different An contents (top: $\mathrm{An}_{15}$ - naturally shocked L6 chondrite;

1532 middle: $\mathrm{An}_{50}$ - experimentally shocked troctolite; bottom: $\mathrm{An}_{94}$ - experimentally shocked

1533 gabbro). The spectral position of the hump in the region of 950 to $1150 \mathrm{~cm}^{-1}$ varies with An

1534 content. Data from Fritz et al. (2019a). 
Table 1: Summary table of impact-related metamorphism in feldspar group minerals, with key to the section of the paper that discusses them in more detail (Column 1: "Sctn.") and relevant figures (Fig.). Reported pressures are in GPa and are derived from ${ }^{[1]}$ Ostertag (1983) and ${ }^{[2]}$ Jaret et al. (2018), both of which conducted shock recovery (gas gun) experiments. These pressures should act as guides and are indicative of trends in the order of formation of shock features, however the exact values may not be directly applicable to natural samples for reasons discussed in Section 4 .

Sctn. Feature

3.1 Irregular fracturing ${ }^{\mathrm{a}}$

3.2 Undulatory extinction

3ave of extinction passes through the grain

3.3 Mosaicism

Patchwork of slightly different extinction angles within a grain

3.4 Planar features/microstructures

Open parallel planar fractures $(\mathrm{PFs})$ and/or

Closely spaced parallel planar lamellae (PDFs)

3.5 Shock darkening

Darkening of mineral in plane-polarised transmitted light

3.7 Diaplectic glass

Amorphous phase that maintains external crystal Partial

form and internal features such as chemical zoning

Complete

3.8 Melt glass

Amorphous phase that shows flow textures and/or vesiculation

3.9 High pressure phases

Phases related to feldspar composition that are stable at higher pressure conditions than found on Earth's surface

3.10 Sieve and checkerboard feldspar

Feldspar clasts in melt rocks made up of individual rectangular domains separated by melt products

3.6 Alternate twin deformation Special cases of planar features or diaplectic glass confined to only
alternate twins

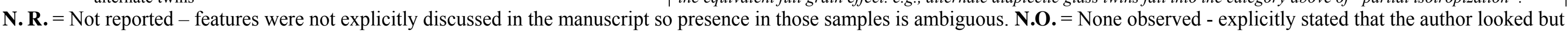

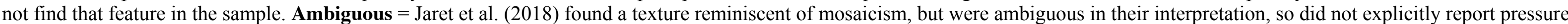

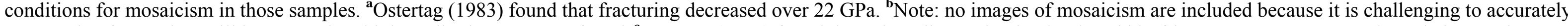

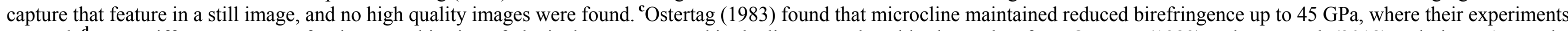

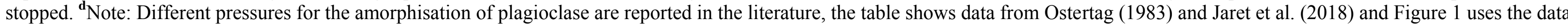

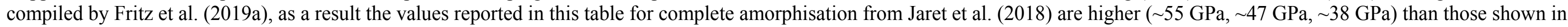

\begin{tabular}{|c|c|c|c|c|c|c|c|}
\hline $\begin{array}{l}\text { Orthoclase } \\
\text { Single } \\
\text { crystal }^{[1]}\end{array}$ & $\begin{array}{l}\text { Sanidine } \\
\text { Single } \\
\text { crystal }^{[1]}\end{array}$ & $\begin{array}{l}\text { Microcline } \\
\text { Single } \\
\text { crystal }^{[1]}\end{array}$ & $\begin{array}{l}\text { Albite } \\
\mathrm{An}_{02}, \text { rock }^{[2]}\end{array}$ & $\begin{array}{l}\text { Oligoclase } \\
\text { Single } \\
\text { crystal }^{[1]}\end{array}$ & $\begin{array}{l}\text { Andesine } \\
\mathrm{An}_{43}, \text { rock }^{[2]}\end{array}$ & $\begin{array}{l}\text { Labradorite } \\
\text { Single } \\
\text { crystal }^{[1]}\end{array}$ & $\begin{array}{l}\text { Bytownite } \\
\mathrm{An}_{77}{ }^{\mathrm{b}}, \operatorname{rock}^{[1]},\end{array}$ \\
\hline$<<10.5$ to 32 & $<<10.5$ to 30 & $<<10.5$ to 34 & $\bar{N}$ N.R. & $<<10.5$ to 29 & $\overline{N . R .}$ & 10.5 to 27 & 10.5 to $26^{\mathrm{a}}$ \\
\hline \multicolumn{8}{|c|}{ No limits explicitly stated } \\
\hline 10.5 to 28 & 14 to 30 & 14 to 45 & Ambiguous & $\sim 18$ to 31 & Ambiguous & 18 to 28 & 22 to $27^{[1]}$ \\
\hline$\sim 10.5$ to 36 & 10.5 to 31 & $\sim 10.5$ to 42 & N.O. & $\sim 14$ to 33 & N.O. & 14 to 23 & $\begin{array}{l}14 \text { to } 27^{[1]} \\
\text { N.O. }\end{array}$ \\
\hline$N . R$. & $N . R$. & $N . R$. & $>\sim 24$ & N.R. & $>\sim 24$ & $N . R$. & $>\sim 22^{[1]}$ \\
\hline$>26-28$ & $>26-28$ & $>26-28$ & $\sim 50-56$ & $\sim 26-28$ & $\sim 28-30$ & $>26-28$ & $\sim 25-27^{[2]}$ \\
\hline$>32-34$ & $>32-34$ & $>45^{\mathrm{c}}$ & $>\sim 55^{\mathrm{d}}$ & $>32-34$ & $>\sim 47^{\mathrm{d}}$ & $>28-30$ & $\begin{array}{l}>28-30^{[1]} ;>\sim 38 \\
{[2]_{\mathrm{d}}}\end{array}$ \\
\hline $45-50^{\mathrm{e}}$ & $45-50^{\mathrm{e}}$ & $45-50^{\mathrm{e}}$ & N.O. & $>42^{\mathrm{e}}$ & N.O. & $>42^{\mathrm{e}}$ & $\begin{array}{l}>45-50^{[1] \mathrm{e}} \\
\text { N.O. }\end{array}$ \\
\hline
\end{tabular}

Temperature rather than pressure is the controlling factor

This is a broad category of effects that each seem to occur over a narrow range of pressure conditions, somewhat lower than See Table 2 
Figure 1 ( $<35 \mathrm{GPa}$ ), likely due to differences in experimental setup and/or plagioclase composition. ${ }^{\mathrm{e}}$ Ostertag (1983) did not detect melt glass unambiguously, so assumed values to be in accordance with Stöffler and Hornemann (1972). 


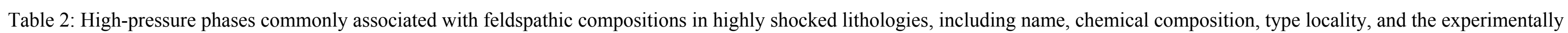

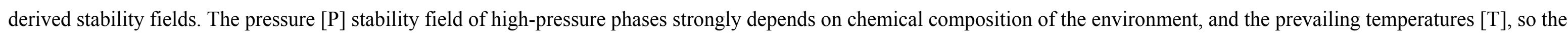
presented P-T conditions serve only as a guide and further details can be found in the cited references.

\begin{tabular}{|c|c|c|c|c|c|c|c|}
\hline Name & Formula & Type Locality & Synthesized & Meteorites & Terrestrial impact structures & $\mathrm{P}-\mathrm{T}$ & Refs. \\
\hline Donwilhelmsite & $\mathrm{CaAl}_{4} \mathrm{Si}_{2} \mathrm{O}_{11}$ & $\begin{array}{l}\text { Lunar meteorite } \\
\text { Oued Awlitis } 001\end{array}$ & Yes & Yes & No & $13-36 \mathrm{GPa},>1200^{\circ} \mathrm{C}$ & $1-3$ \\
\hline Jadeite & $\mathrm{NaAlSi}_{2} \mathrm{O}_{6}$ & Myanmar & & Yes & Yes & $2.5 \mathrm{GPa} ; 1000{ }^{\circ} \mathrm{C}$ & $4-9$ \\
\hline $\begin{array}{l}\text { Liebermannite } \\
\text { (K-Hollandite) }\end{array}$ & $\mathrm{KAlSi}_{3} \mathrm{O}_{8}$ & $\begin{array}{l}\text { Martian meteorite } \\
\text { Zagami }\end{array}$ & Yes & & & $12 \mathrm{GPa}, 1026^{\circ} \mathrm{C}$ & $10-16$ \\
\hline $\begin{array}{l}\text { Lingunite } \\
\text { (Na-Hollandite) }\end{array}$ & $\mathrm{NaAlSi}_{3} \mathrm{O}_{8}$ & Sixiangkou L6 chondrite & Yes & Yes & Yes & $\begin{array}{l}\text { Stable at } 22-23 \mathrm{GPa} ;>1200{ }^{\circ} \mathrm{C} \\
\text { Metastable at } \sim 20-24 \mathrm{GPa} ; \sim 1100-1300{ }^{\circ} \mathrm{C}\end{array}$ & $11-15,17-22$ \\
\hline $\begin{array}{l}\text { Tissintite } \\
\text { Zagamiite }\end{array}$ & $\begin{array}{l}(\mathrm{Ca}, \mathrm{Na}, \square) \mathrm{AlSi}_{2} \mathrm{O}_{6} \\
\mathrm{CaAl}_{2} \mathrm{Si}_{3.5} \mathrm{O}_{11}\end{array}$ & $\begin{array}{l}\text { Martian meteorite Tissint } \\
\text { Martian meteorite Zagami }\end{array}$ & Yes & Yes & & $6-8.5 \mathrm{GPa} ; 1000-1350^{\circ} \mathrm{C}$ & $\begin{array}{l}23,24 \\
23-26\end{array}$ \\
\hline
\end{tabular}

Zagamiite $\quad \mathrm{CaAl}_{2} \mathrm{Si}_{3.5} \mathrm{O}_{11} \quad$ Martian meteorite Zagami

Yes

Metastable at $\sim 20-24 \mathrm{GPa} ; \sim 1100-1300{ }^{\circ} \mathrm{C}$

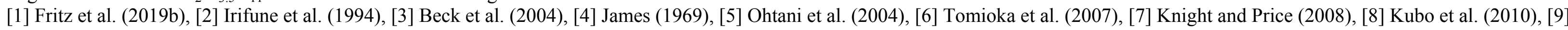

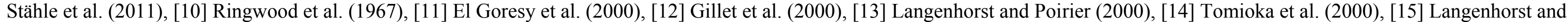

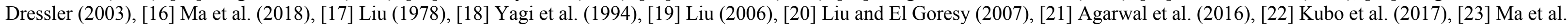

(2015), [24] Rucks et al. (2018), [25] Walton et al. (2014), [26] Ma et al. (2017).

Table 3: Summary of different experimental techniques for calibrating shock features and parameters.

\begin{tabular}{|c|c|c|c|c|}
\hline Technique & Timescale & Method & Purpose & References \\
\hline Shock & Nanoseconds & $\begin{array}{l}\text { In situ measurements of } \\
\text { shockwaves }\end{array}$ & $\begin{array}{l}\text { Determination of the equation of state (EoS) using } \\
\text { Rankine-Hugoniot relations (Fig. 2) }\end{array}$ & Wackerle (1962) \\
\hline Shock recovery & $\begin{array}{l}\text { Shock pulses of } \\
\text { microsecond duration }\end{array}$ & $\begin{array}{l}\text { Shock impedence or } \\
\text { reverberation technique }\end{array}$ & $\begin{array}{l}\text { Investigations of shock effects in materials } \\
\text { Determination of phase stability }\end{array}$ & $\begin{array}{l}\text { Müller and Hornemann (1969); Hörz and Quaide } \\
\text { (1973); Fritz et al. (2011) }\end{array}$ \\
\hline $\begin{array}{l}\text { Rapid } \\
\text { compression }\end{array}$ & Seconds $-10 \mathrm{~s}$ mins & $\begin{array}{l}\text { Membrane and dynamic } \\
\text { diamond anvil cell }\end{array}$ & $\begin{array}{l}\text { Determination of phase stability } \\
\text { Typically collect simultaneous XRD during compression } \\
\text { and decrompression }\end{array}$ & $\begin{array}{l}\text { Letoullec et al. (1988); Evans et al. (2007); Sims et } \\
\text { al. (2019) }\end{array}$ \\
\hline $\begin{array}{l}\text { Static } \\
\text { compression }\end{array}$ & Minutes to hours & Diamond anvil cell & $\begin{array}{l}\text { Determination of phase stability } \\
\text { Typically coupled with either XRD or Raman } \\
\text { spectroscopy after each compression step }\end{array}$ & $\begin{array}{l}\text { Angel (1988); Williams and Jeanloz (1988); Daniel } \\
\text { et al. (1997); Sims et al. (2020) }\end{array}$ \\
\hline
\end{tabular}


Table 4: Summary of analytical techniques used for assessing shock in feldspars. Optical microscopy is not included as it is assumed that primary characterization has already been conducted.

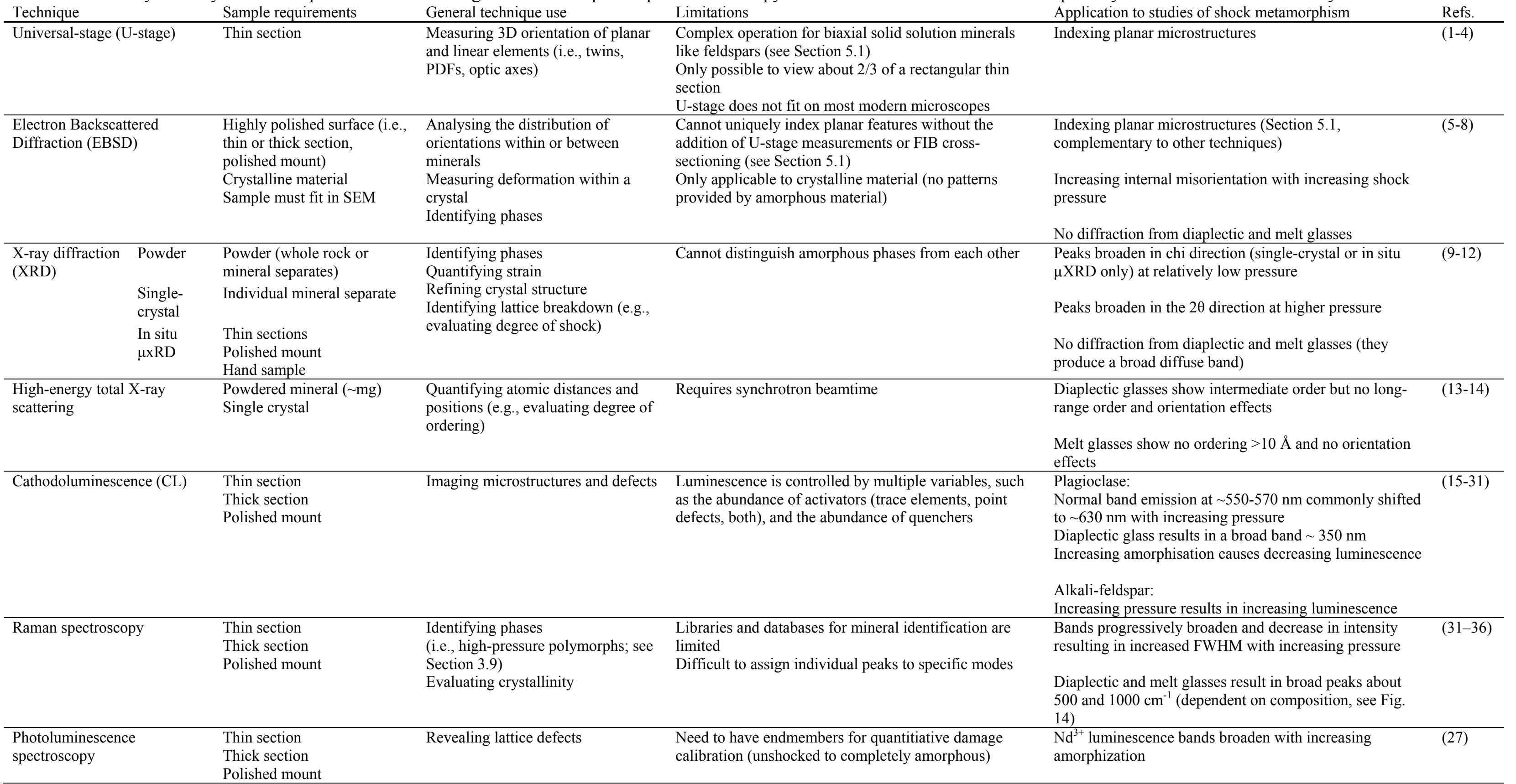


Thermal infrared absorption spectroscopy

Powder (whole rock or

Identifying phases

mgs)

Micro FTIR spectroscopy Thin section

\section{Thick section}

Polished mount

\section{Powder (whole rock or}

mineral separates) $(\mathrm{mgs}-10$

mgs)
Identifying phases environment
Orientation sensitive measurements (e.g., peak height)

can be hard to match to databases of non-oriented measurements

Averages grail

Limited sensitivity to minor components of the mixture

(1)

Sample must

in feldspars)
Decreased spectral detail and intensity with increasing pressure

Loss of low wavenumber peaks (as a result of lattice disordering and increased glass content) with increasing pressure

Diaplectic and melt glass result in one broad peak Decreased intensity of peaks due to loss of crystallinity with increasing pressure

Diaplectic glass preserves orientation effects

Melt glass does not preserve orientation effects

Diaplectic glass lacks long range order, results in a spectral shape similar to melt glass, but peak centre and FWHM are more similar to crystalline plagioclase

Melt glass lacks long range order, and results in broader spectral peak than crystalline plagioclase or diaplectic plagioclase glass

\footnotetext{
[1] Reinhard (1931), [2] Turner (1947), [3] Stöffler (1967), [4] Dworak (1969), [5] Prior et al. (1999), [6] Pickersgill et al. (2017), [7] Pickersgill and Lee (2015), [8] Pittarello et al. (2020a), [9]

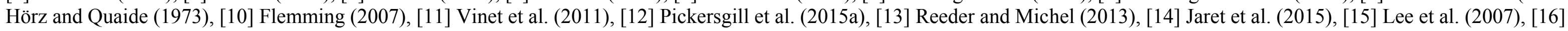

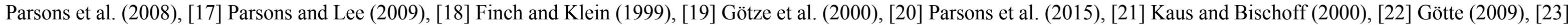

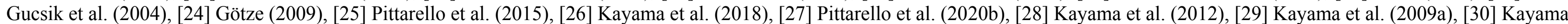

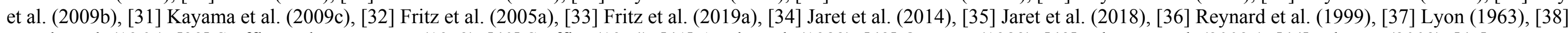

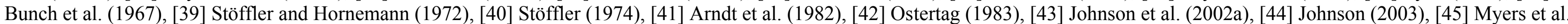
(1998).
} 
Table 5: Summary table of orientations of shock-induced planar microstructures in feldspars measured by U-stage.

Feldspar composition Reported orientation(s)

Crater

References

Labradorite

(001), (010), (111), (203), (101)

Andesine $\left(\sim \mathrm{An}_{30}\right)$

(001) $25 \%,(010) 11 \%,(100) 10 \%$

requency

Plagioclase

(001), (010), (102), and (1 $\overline{2} 1)$

$\mathrm{An}_{98}$

(101), (010), (021)
Manicouagan

Ries

Dworak (1969)

Stöffler (1967)

Several Canadian craters Robertson et al. (1968)

Apollo breccia 10046

Dence et al. (1970) 
Figure 1

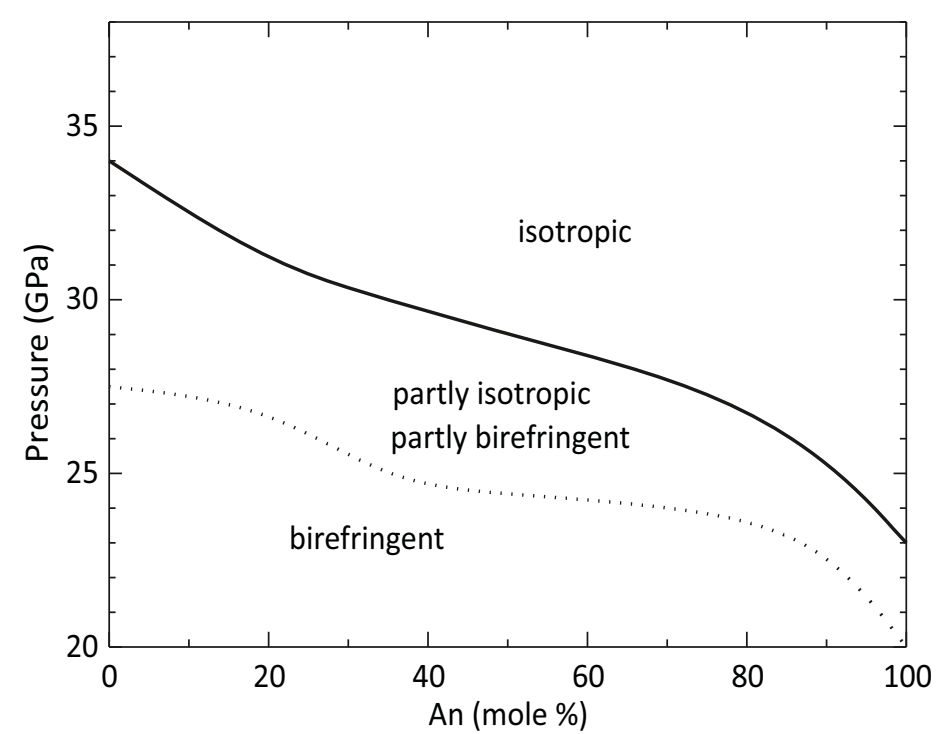




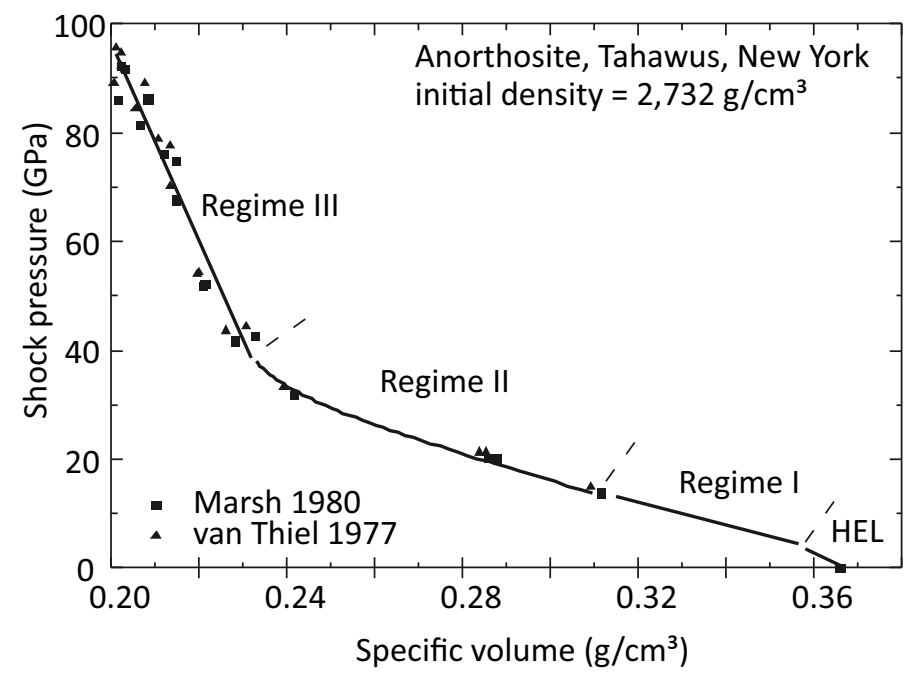




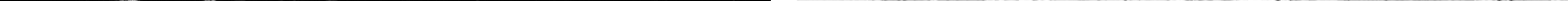




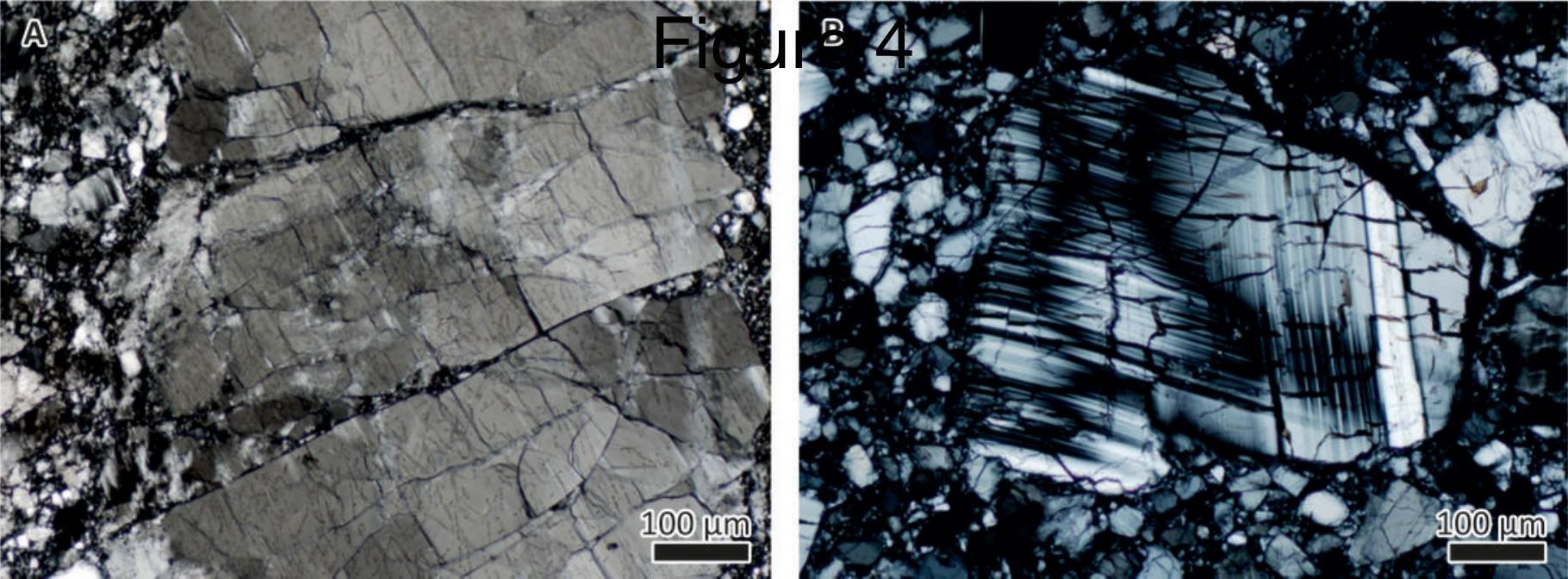




\section{A}
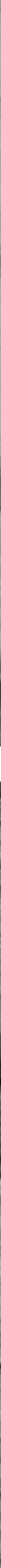


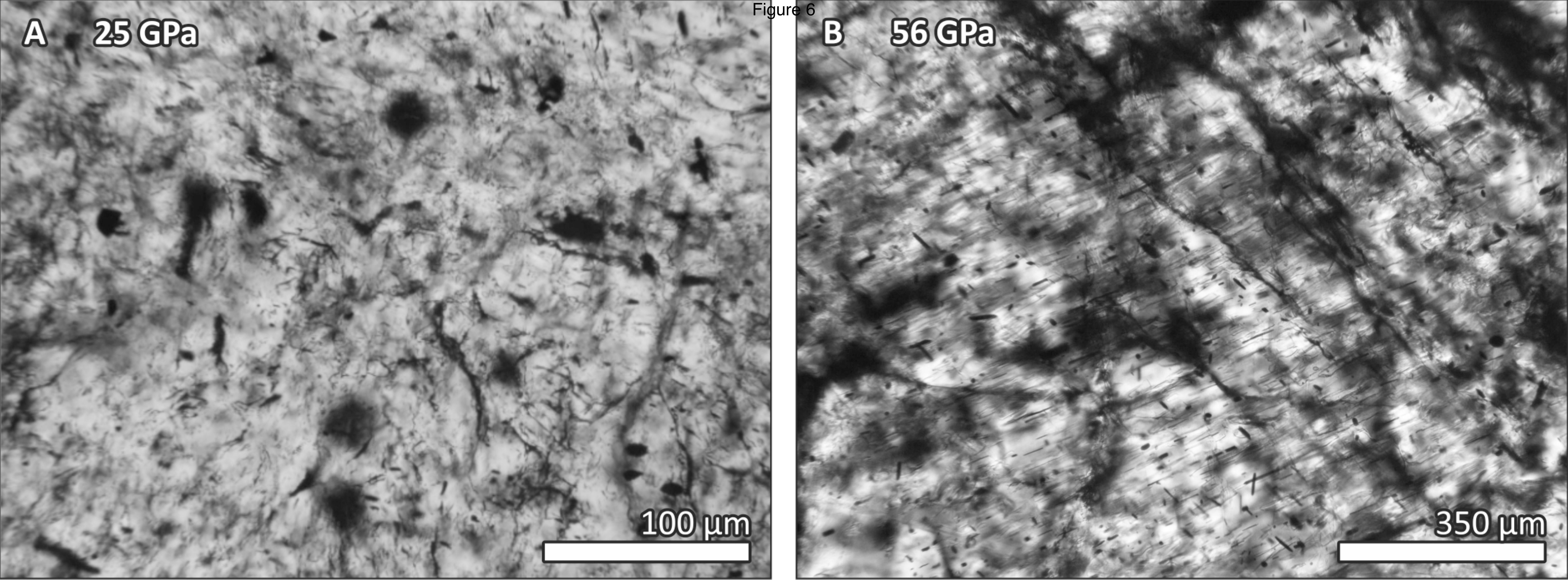


Figure 8
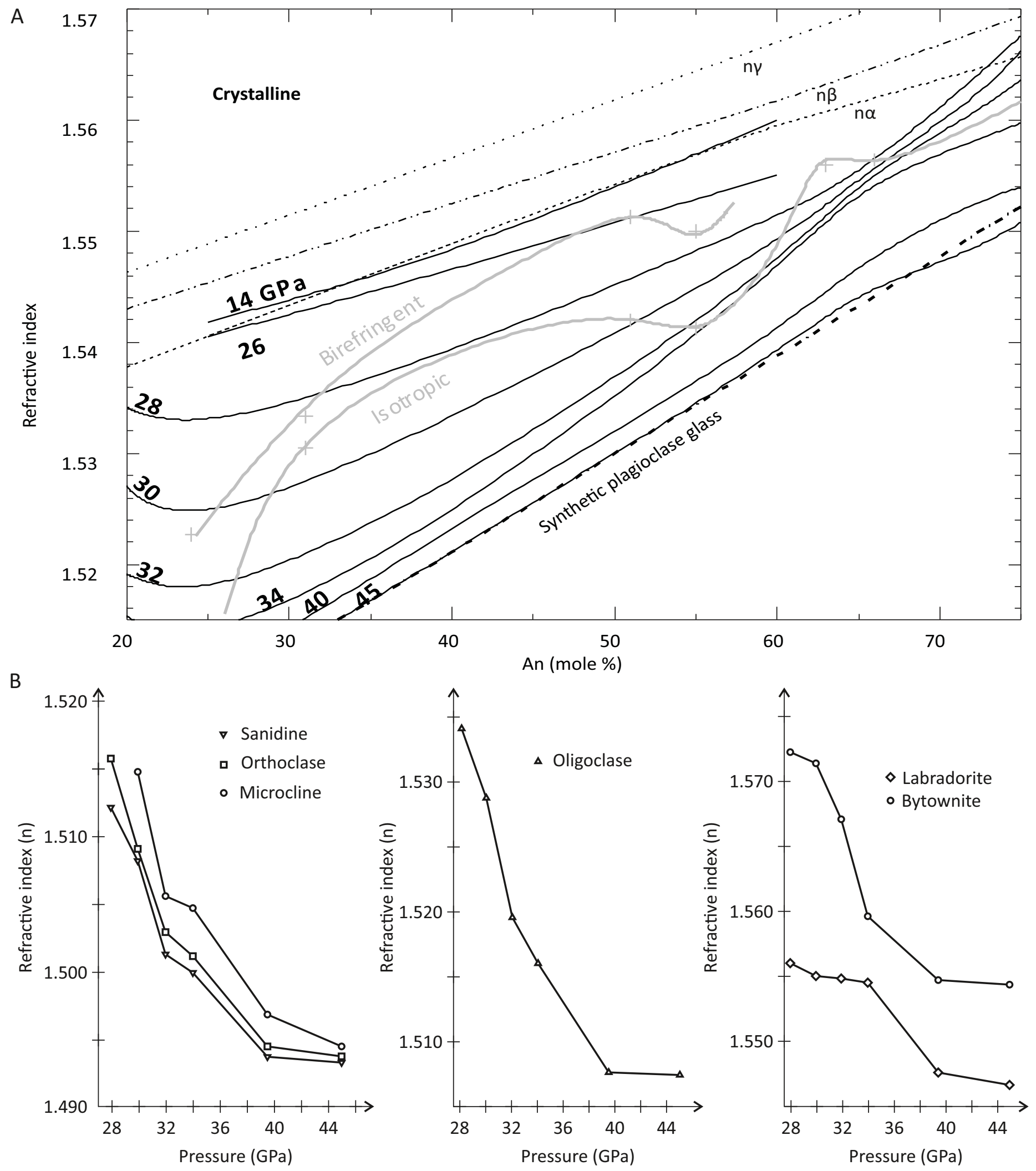

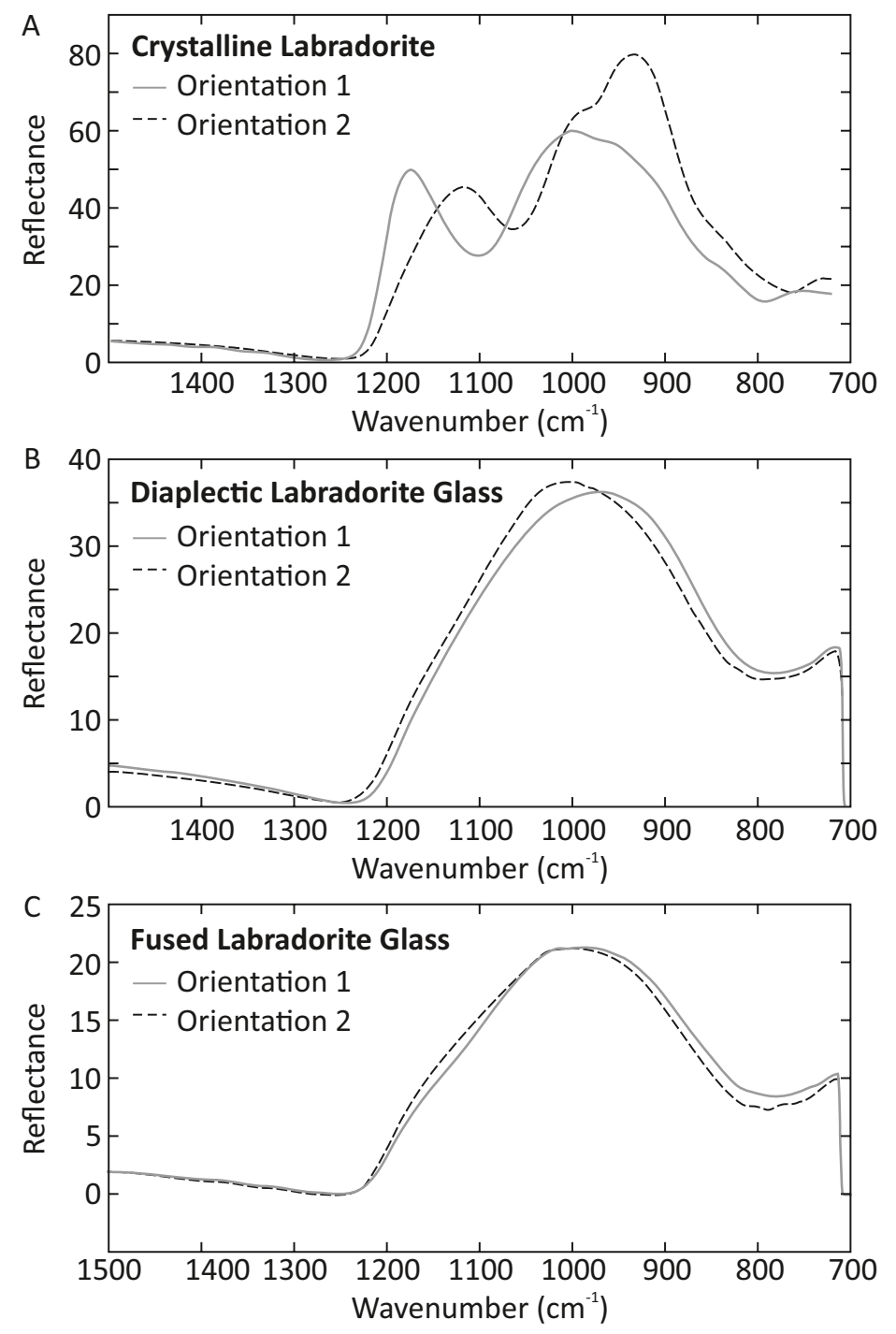


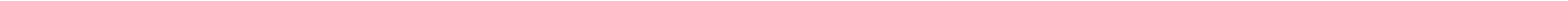




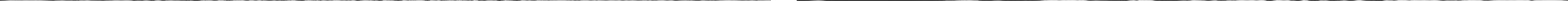



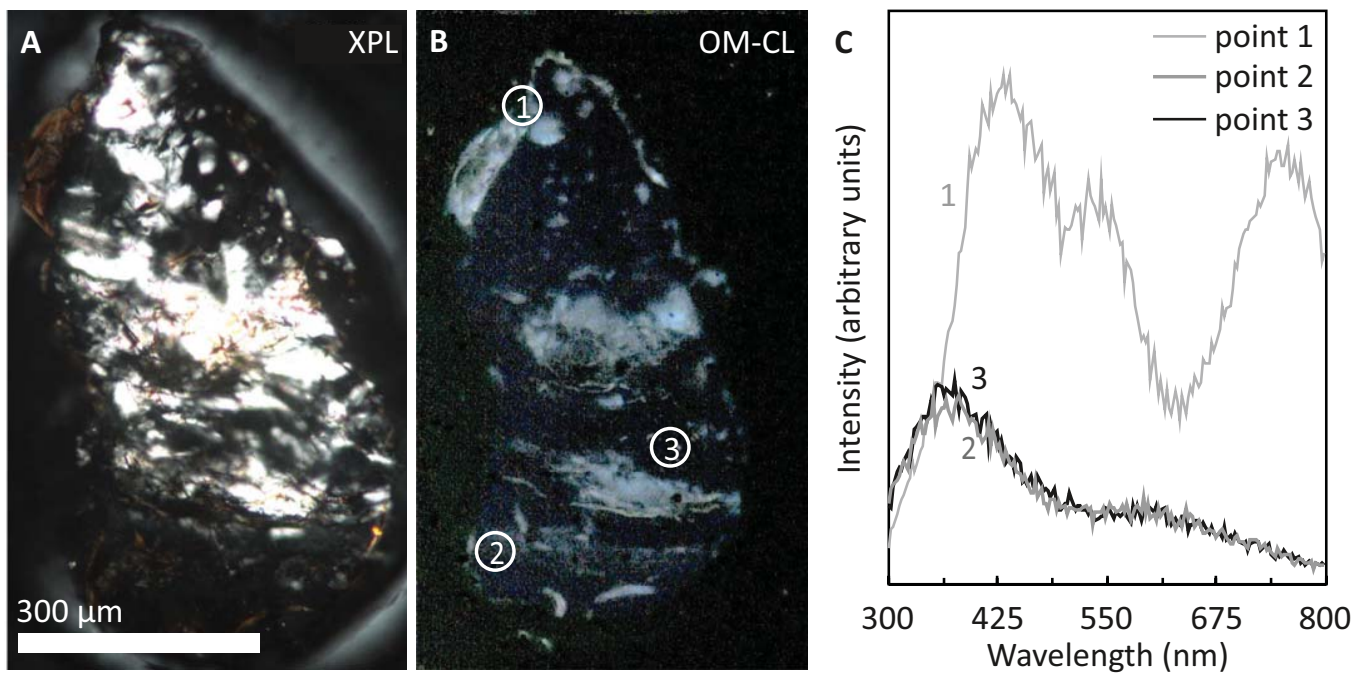

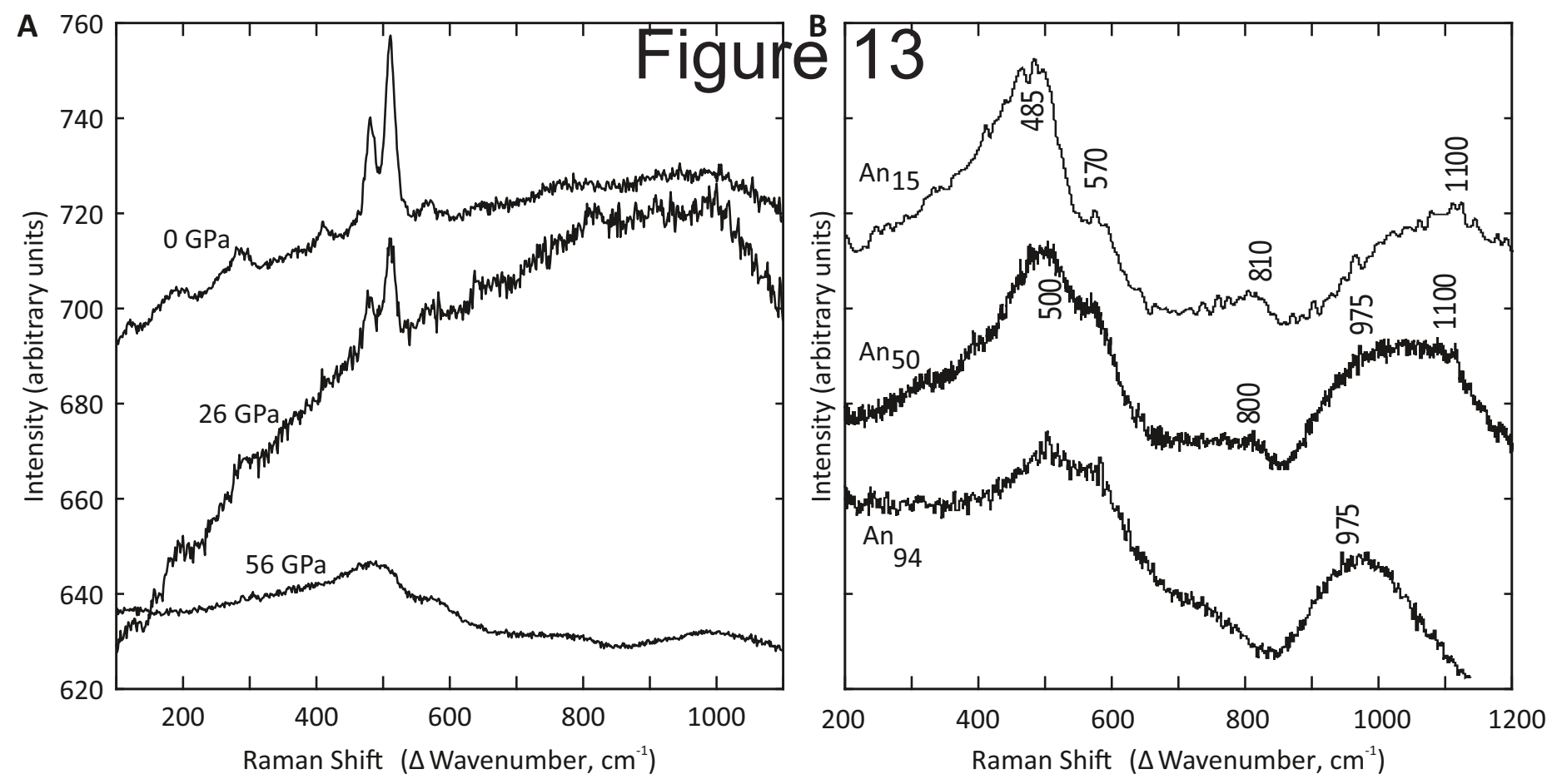